This is an Open Access version of the article: Vannoppen, W., Vanmaercke, M., De Baets, S., Poesen, J. (2015). A review of the mechanical effects of plant roots on concentrated flow erosion rates. Earth-Science Reviews 150: 666-678.

DOI: 10.1016/j.earscirev.2015.08.011

\title{
A review of the mechanical effects of plant roots on concentrated flow erosion rates
}

\author{
W. Vannoppen ${ }^{1}$, M. Vanmaercke ${ }^{1,2}$, S. De Baets ${ }^{3}$, J. Poesen $^{1}$
}

\footnotetext{
${ }^{1}$ Division of Geography and Tourism, KU Leuven, Celestijnenlaan $200^{\mathrm{E}}$, B-3001 Heverlee, Belgium

${ }^{2}$ Research Foundation Flanders (FWO), Brussels, Belgium

${ }^{3}$ School of Geography, University of Exeter, Amory Building-D438, Rennes Drive, Exeter EX4 4RJ, UK Corresponding author: W. Vannoppen:Wouter.vannoppen@ees.kuleuven.be
}

\begin{abstract}
:
Living plant roots modify both mechanical and hydrological characteristics of the soil matrix (e.g. soil aggregate stability by root exudates, soil cohesion, infiltration rate, soil moisture content, soil organic matter) and negatively influence the soil erodibility. During the last two decades several studies reported on the effects of plant roots in controlling concentrated flow erosion rates. However a global analysis of the now available data on root effects is still lacking. Yet, a meta-data analysis will contribute to a better understanding of the soil-root interactions as our capability to assess the effectiveness of roots in reducing soil erosion rates due to concentrated flow in different environments remains difficult. The objectives of this study are therefore: i) to provide a state of the art on studies quantifying the effectiveness of roots in
\end{abstract}


reducing soil erosion rates due to concentrated flow; and ii) to explore the overall trends in erosion reduction as a function of the root (length) density, root architecture and soil texture, based on an integrated analysis of published data. We therefore compiled a dataset of measured soil detachment ratios (SDR) for the root density (RD; 822 observations) as well as for the root length density (RLD; 274 observations). A Hill curve model best describes the decrease in SDR as a function of R(L)D. An important finding of our meta-analysis is that RLD is a much more suitable variable to estimate SDR compared to RD as it is linked to root architecture. However, a large proportion of the variability in SDR could not be attributed to RD or RLD, resulting in a low predictive accuracy of these Hill curve models with a model efficiency of 0.11 and 0.17 for RD and RLD respectively. Considering root architecture and soil texture did yield a better predictive model for RLD with a model efficiency of 0.37 for fibrous roots in non-sandy soils while no improvement was found for RD. The unexplained variance is attributed to differences in experimental set-ups and measuring errors which could not be explicitly accounted for due to a lack of additional data. Based on those results, it remains difficult to predict the effects of roots on soil erosion rates. However, by using a Monte Carlo simulation approach, we were able to establish relationships that allow assessing the likely erosion-reducing effects of plant roots, while taking these uncertainties into account. Overall, this study demonstrates that plant roots can be very effective in reducing soil erosion rates due to concentrated flow.

Key words: Concentrated flow erosion, Soil detachment rates, Root density (RD), Root length density (RLD), Root architecture, Soil texture

\section{Contents}

\section{Introduction}

2. Erosion-reducing potential of roots: mechanisms and controlling factors

2.1 Mechanisms of plant roots in reducing soil erosion

2.2 Factors controlling the erosion-reducing potential of plant roots 
Final paper available at: http://www.sciencedirect.com/science/article/pii/S0012825215300350

3. Quantifying the erosion-reducing potential of root systems: methodology

3.1 Data collection and standardization

3.2 Statistical analysis

4. Quantifying the erosion-reducing potential of roots systems: results of the meta-analsysis

4.1 Effects of root density (RD) and root length density (RLD) on soil detachment ratios (SDR)

4.2 Effects of root architecture and soil texture on the erosion-reducing potential of roots

4.3 Assessment of uncertainty ranges on the erosion-reducing potential of plant roots

5. Conclusions

\section{Introduction}

Vegetation is frequently used in ecological restoration programs to reduce the severe impact of soil erosion processes on e.g. agricultural fields, steep slopes, side walls along roads and levees (e.g. Gray and Leiser, 1982; Thornes, 1990; Morgan and Rickson, 1995; Morgan, 2005; Stokes et al., 2007; Blanco and Lal, 2008; Norris et al., 2008; Maetens et al., 2012; Stokes et al., 2014). Vegetation cover can prevent soil erosion in several ways: 1) it provides protection of the soil surface against raindrop impact and against erosion by surface runoff, 2) it reduces runoff volume and velocity by increasing infiltration rate and surface roughness and 3) it reduces sediment transport by trapping sediments (e.g. Rey, 2003, 2004; Morgan, 2005; Blanco and Lal, 2008; Zuazo and Pleguezuelo, 2008; Gumiere et al., 2011).

Most studies on the effectiveness of vegetation in reducing soil erosion mainly focused on the effects of above-ground vegetation as the effects of plant roots in controlling soil erosion rates are much more difficult to study and often referred to as 'the hidden half' (Eshel and Beeckman, 2013). As a consequence, the role of below-ground vegetation in controlling erosion processes have been less studied (Poesen et al., 2003; Gyssels et al., 2005; Reubens et al., 2007; Stokes et al., 2014).

Nevertheless, studies from the last two decades indicate that plant roots play a dominant role in reducing soil detachment rates due to concentrated flows and can therefore be very effective in controlling rill and gully erosion (e.g. Gyssels et al., 2005; De Baets and Poesen, 2010). This is highly relevant because rill, 
gully and bank erosion often contribute significantly to catchment sediment yield and to off site impacts such as flooding and reservoir sedimentation (e.g. Poesen et al., 2003; de Vente and Poesen, 2005; Vanmaercke et al., 2011, 2012). Also in the light of the predicted climate changes and sea level rises (IPCC, 2013), root systems can play a crucial role in protecting levees against the erosive effects of waveovertopping (e.g. Hoffmans et al., 2008; Quang and Oumeraci, 2012).

The erosion-reducing potential of plant roots are the result of complex interactions within the root-soil matrix changing the mechanical and hydrological properties of the soil (e.g. Eviner and Chapin, 2003; Gregory, 2006). As a result, the effectiveness of plant roots in reducing concentrated flow erosion rates is influenced by several root and soil characteristics: e.g. root (length) density, root architecture, soil texture, soil moisture and dry soil bulk density (e.g. De Baets et al., 2007a; Burylo et al., 2012). Differences in the erosion-reducing potential of different plant root systems call for a selection of the most appropriate plant species in programs of erosion control or hillslope stabilization (e.g. De Baets et al., 2007b, 2009; Stokes et al., 2009; Reubens et al., 2011; Burylo et al., 2014; Mwango et al., 2014). However, the extrapolation of the relationships between root properties and erosion rates, observed in individual case studies, to other sites, with differences in climate, root and soil characteristics, remains difficult (Stokes et al., 2014).

What is currently lacking is a meta-analysis of studies quantifying the erosion-reducing potential of root systems during concentrated flow. Such meta-analysis is a first step in the development of a general model that allows estimating the erosion-reducing potential of roots, based on factors that are known to be relevant. The main objectives of this research are therefore: i) to provide a state of the art on studies quantifying the effectiveness of roots in reducing soil erosion due to concentrated flow; and ii) to explore the overall trends in erosion reduction as a function of the root (length) density, root architecture and soil texture, based on an integrated analysis of published data. First an overview is given of studies reporting on the effects of plant roots in reducing rates of erosion processes by water together with factors that control this erosion-reducing potential. Next, a quantitative analysis of all experimental data is made in order to explore the overall trend in root effects on concentrated flow erosion rates. As such, this study 
represents a progress toward a better understanding of the mechanical effects of plant root characteristics on concentrated flow erosion rates in a range of environments.

\section{Erosion-reducing potential of roots: mechanisms and controlling factors}

To provide an overview of root effects on erosion processes by water, i.e. splash detachment, interrill erosion, rill and gully erosion and river bank erosion, an extensive literature review was made resulting in 36 empirical studies. Table 1 gives an overview of these studies describing the erosion processes considered, the investigated root characteristics, the overall root effects on soil erosion rates and the methods used. Several methods have been used, either in the field or in the laboratory, to measure the erosion-reducing effects of plant roots. Laboratory experiments include rainfall simulations (e.g. Ghidey and Alberts, 1997; Katuwal et al., 2013) and hydraulic flume tests (e.g. Mamo and Bubenzer, 2001a; De Baets et al., 2006). Field measurements and experiments include the use of rainfall simulations (e.g. Li et al., 1991; Cogo and Streck, 2003), micro erosion plots (e.g. Pierret et al., 2007b), concentrated flow simulations (e.g. Mamo and Bubenzer, 2001b; Li and Li, 2011), measurements of rill and gully densities (Li et al., 2015) and rill and (ephemeral) gully cross sections (e.g. Gyssels et al. 2002). A large variability in measured root morphological traits and erosion variables is observed. Root density $\left(R D, \mathrm{~kg} \mathrm{~m}^{-3}\right)$ and root length density $\left(R L D, \mathrm{~km} \mathrm{~m}^{-3}\right)$ are the most commonly used root characteristics, representing respectively the dry mass and the total length of the living plant roots in a certain volume of soil. Also a large variability exists in the reported erosion variables which can be divided into: 1) variables related to soil detachment rates $\left(D_{r}, \mathrm{~kg} \mathrm{~m}^{-2} \mathrm{~s}^{-1}\right)$ and 2) variables related to soil erodibility $(K)$.

Only two studies investigated the effect of plant roots on splash detachment. While Ghidey and Alberts (1997) reported no root effect on splash erosion the study of Katuwal et al. (2013) showed a significant negative effect of below-ground biomass on splash erosion rate. The effects of plant roots on interrill erosion are also not univocal. Bui and Box (1993) and Pierret et al. (2007b) found no significant root effects. Those findings contrast with studies reporting significant effects of plant roots on 1) interrill detachment rates (Zhou and Shangguan (2007, 2008); Katuwal et al., 2013) and 2) interrill erodibility $\left(\mathrm{K}_{\mathrm{i}}\right)$ 
(Ghidey and Alberts (1997), Katuwal et al., 2013). The interrill erodibility $\left(\mathrm{K}_{\mathrm{i}}\right)$ can be estimated based on the relationship between soil detachment, slope and the rainfall intensity or runoff discharge (e.g. Meyer and Harmon, 1984; Kinell, 1993; Ghidey and Alberts, 1997). For rill and gully erosion (i.e. concentrated flow erosion) all case studies reported a significant erosion-reducing effect on soil detachment rates $\left(D_{r}\right)$ as well as on soil erodibility $\left(\mathrm{K}_{\mathrm{r}}\right.$; Eq. 1) (Table 1).

Experiments with both above- and below-ground biomass indicated that vegetation cover was more effective in reducing splash detachment (Katuwal et al., 2013) while plant roots were more efficient in reducing (inter-)rill erosion (Zhou and Shangguan, 2008; Zhang et al., 2012). Sigunga et al. (2015) showed that roots of Eucalyptus citriodora trees fused, forming a dense network of closely woven mass of roots holding large amounts of soil and thereby controlling erosion by water and hence gully development. Fig. 1 shows a structural model comparing the erosion-reducing potential of plant roots and plant cover. While plant roots are more effective in controlling rill and gully erosion rates, plant cover is more effective in controlling splash detachment and interrill erosion rates (Gyssels et al., 2005; Zuazo and Pleguezuelo, 2008).

The intensity of concentrated flow erosion is most often based on excess shear stress models and can be expressed as a soil detachment rate $\left(D_{r}\right)$ in relation to the soil erodibility $(K)$ and the critical flow shear stress $\left(\tau_{c r}\right)$ (e.g. Meyer, 1964; Lane et al., 1987; Nearing et al., 1997; Zhu et al., 2001; Knapen et al., 2007b):

$D_{r}=K_{C}\left(\tau-\tau_{c r}\right)^{b}$

Where $D_{\mathrm{r}}\left(\mathrm{kg} \mathrm{m}^{-2} \mathrm{~s}^{-1}\right)$ is the soil detachment rate, $K_{\mathrm{c}}\left(\mathrm{s} \mathrm{m}^{-1}\right)$ is the concentrated flow soil erodibility, $\tau(\mathrm{Pa})$ is the average flow shear stress, $\tau_{c r}(\mathrm{~Pa})$ the critical flow shear stress for incipient soil detachment and $\mathrm{b}$ is an exponent. $K_{C}, \tau_{c r}$ and $\mathrm{b}$ are empirical parameters depending on land use practices and soil properties (i.e. physical, chemical and biological properties) (e.g. Knapen et al., 2007b).

This approach based on eq. 1 was also used to develop a threshold equation for gully head development (Montgomery and Dietrich, 1994). Recently, Torri and Poesen (2014) contributed to this and developed an 
approach in which the effects of vegetation (e.g. the effect of roots on increased erosion resistance) on the development of gullies are incorporated more explicitly. The direct and indirect effects of plant roots on the soil erodibility factor $\left(\mathrm{K}_{\mathrm{C}}\right)$ and $\tau_{c \mathrm{r}}$ from Eq. 1, resulting in a reduction of soil detachment rates, will be discussed in section 2.1 .

\subsection{Mechanisms of plant roots in reducing soil erosion}

To understand the role of plant roots in controlling concentrated flow erosion rates, one has to consider the root-soil system which is complex (Fig. 2) due to mutual interactions between soil and root characteristics (e.g. McCully, 1999; Gregory, 2006).

As such, root growth within in the soil will induce biophysical and biochemical reactions in the adjacent soil which modify its mechanical and hydrological characteristics (e.g. Angers and Caron, 1998; Simon and Collison, 2002; Eviner and Chapin, 2003; Whalley et al., 2005). The presence of roots will affect the mechanical properties of the soil in two ways (Fig. 2). In the first place by increasing soil aggregate stability (e.g. Amézketa, 1999; Bronick and Lal, 2005). Mechanically, roots will interweave in the soil matrix and serve as a framework for the formation of aggregates (Reubens et al., 2007). Also root exudates, e.g. mucilage secretion at the root cap, enhance the formation of water-stable aggregates by binding the soil particles together through their adhesive properties (e.g. Jastrow et al., 1998; McCully, 1999; Jones et al., 2009). Soil aggregates need some time to develop and the root effects are not immediately in time (e.g. Traoré et al., 2000; Abiven et al., 2009). Furthermore, aggregate stability is indirectly influenced by the activity of microorganisms which feed on those organic substances and in turn produce polysaccharides that enhance the formation of soil aggregates (Gregory, 2006). Besides this, root exudates also serve as a continual source of organic matter which will increase the soil structure (Jastrow et al., 1998; Bronick and Lal, 2005; Fattet et al., 2011). Soil aggregate stability is negatively correlated to soil erodibility $\left(K_{C}\right)$ (Knapen et al., 2007b; Wang et al., 2011). The erosion-reducing effects of plant roots are thus partly resulting from their positive effect on aggregate stability (e.g. Ghidey and Alberts, 1997; Pohl et al., 2009; Du et al., 2010; Fattet et al., 2011; Li and Li, 2011). Several studies found a direct 
negative effect of plant roots on $K_{C}$ which becomes stronger with increasing $R D$ or $R L D$ (e.g. Mamo and Bubenzer, 2001a,b; Gyssels et al., 2006; Knapen et al., 2007a, De Baets and Poesen, 2010; Knapen and Poesen, 2010; Zhang et al., 2013; Wang et al., 2014). The soil erodibility factor $\left(\mathrm{K}_{\mathrm{C}}\right)$ is related to many other variables and acts as a black-box coefficient (e.g. Knapen, 2007b; Borselli et al., 2012). As a result, $\mathrm{K}_{\mathrm{C}}$ can be substituted in Eq. 1 by correlated variables in order to determine soil detachment rates $\left(D_{r}\right)$. Zhang et al. (2013) found that $60 \%$ of the variability in $D_{r}$ could be explained by flow shear stress $(\tau)$ and $R D$, assuming a constant $\tau_{c r}$. This is in agreement with other studies reporting a significant influence of $R D$ or RLD together with $\tau$ on $D_{r}$ (e.g. De Baets and Poesen, 2010; Wang et al., 2011; Moody and Nyman, 2012).

Next to an increased aggregate stability, plant roots will also modify the mechanical properties of the soil by reinforcing the soil matrix. As plant roots can well resist tension forces while the soil matrix is strong in compression, they are complementary to each other (Simon and Collison, 2002). This will lead to an increased soil shear strength due to the presence of roots (e.g. Wu, 1976; Pollen and Simon, 2005). The potential of plant roots to stabilize the soil by their additional soil shear strength is often applied on slopes that are threatened by shallow mass movements (e.g. Norris et al., 2008; Mao et al., 2012; Stokes et al., 2014). The degree of soil reinforcement by plant roots is highly plant specific and depends on the root system characteristics, e.g. root architecture and root tensile strength (e.g. Reubens et al., 2007; De Baets et al., 2008a). The root tensile strength (MPa) is negatively related to the root diameter (Mao et al., 2012) which can be attributed to the lower cellulose content of thicker roots (Genet et al., 2005). When predicting concentrated flow erosion rates, the soil shear strength is also important to consider as it is positively related to the critical flow shear stress $\left(\tau_{c r}\right)$ (e.g. Léonard and Richard, 2004; Knapen et al., 2007b; Wang et al., 2011) and negatively related to the soil erodibility $\left(\mathrm{K}_{\mathrm{C}}\right)$ (e.g. Torri, 1987). De Baets et al. (2008b) incorporated the root effects on soil cohesion within the soil erosion model EUROSEM by linking root densities to the increased soil cohesion values due to the presence of roots. At the moment, very few experimental data exist on the relation between soil shear strength, root properties and the 
resulting soil detachment rates as there are large practical difficulties involved in measuring the soil shear strength of root-permeated soils (e.g.Wang et al., 2011, 2014; Katuwal et al., 2013, Yu et al., 2014).

Both soil shear strength and soil aggregate stability are positively related to each other as they have to some extent similar bonding mechanisms (Fattet et al. 2011). For example mycorrhizal fungi, which are commonly associated with fine roots (Jastrow et al., 1998), are involved in the formation of water-stable aggregates and will enhance soil shear strength (e.g. Fattet et al., 2011; Leifheit et al., 2014). As a larger soil volume is affected due to the larger extent of soil exploration by those fungi compared to the root system itself (Johnson and Gehring, 2007), mycorrhizal fungi are also important to consider within erosion control measures next to plant roots.

In addition to these mechanical properties, root growth also influences the hydrological properties of the soil matrix (Simon and Collison, 2002) as their function is to allocate water and nutrients to the aboveground parts (Gregory, 2006). This in turn will influence soil aggregation by the localized drying (Amézketa, 1999). Li et al. (1992) found a positive correlation between the presence of fine roots $(<1 \mathrm{~mm})$ and the soil permeability as those fine roots are associated with the formation of water-stable aggregates (Fattet et al., 2011). An increased permeability will result in an increased infiltration rate and a reduction of surface runoff rate. A higher amount of roots will also facilitate the allocation of water and thereby decreasing soil water content and thereby increasing the soil shear strength (Normaniza and Barakbah, 2006). The root system type is important to consider as fibrous roots reduce the macro-pore space available for water movement while coarse roots facilitate water movement to deeper soil layers (Archer et al., 2002).

\subsection{Factors controlling the erosion-reducing potential of plant roots}

The erosion-reducing effects of plant roots are both depending on the amount of roots within the soil matrix (often expressed as $R D$ and $R L D$ ) and on specific root properties (e.g. root architecture, diameter, tensile strength or rooting depth) as shown in Fig. 2. Root properties and root development are strongly plant-specific which can be genetic or phenotypic in nature (Gregory, 2006). The root architecture of 
plants is important to consider as it will determine the erosion-reducing potential of plant roots (e.g. Reubens et al., 2007; Stokes et al., 2009; Burylo et al., 2014). A twofold classification in fibrous and tap root systems is most widely used (Fitter, 1987). Fibrous root systems consist of many fine equivalent roots while tap root systems consist of central and vertical main roots with a limited number of laterals and reduced branching compared to fibrous root systems (Cannon, 1949). Nonetheless, these two root systems only represent the extremes of a continuum of different root architectural forms (Fitter, 1987). Research indicates that, in general, fibrous root systems are more effective in reducing soil erosion compared to tap root systems (e.g. Reubens et al., 2007; De Baets et al., 2007a; Stokes et al., 2009). This can be attributed to the larger root-soil contact area for fibrous roots due to the large number of fine roots (Zhou and Shangguan, 2005; De Baets et al., 2007a) which will enhance the formation of water-stable aggregates (Jastrow et al., 1998). Li et al. (2015) found a significant decrease in rill and gully channel density on slopes with increasing fine root density $(<2 \mathrm{~mm})$ which is in line with Burylo et al. (2012) who found a significant negative correlation between the soil detachment ratio $(S D R)$ and the percentage of fine roots $(<0.5 \mathrm{~mm})$.

The high level of variability in root characteristics, even within a single plant species depends to a large extent on the environment and management practices (Fig. 2). Both factors affect root growth and root characteristics and will indirectly influence the erosion-reducing potential of plant roots. In a global study of topsoil root densities Jackson et al. (1996) showed large differences in root densities among terrestrial biomes. Highest root densities within the topsoil were reported for tropical evergreen forests and sclerophyllous scrub vegetation with $R D$ values exceeding $40 \mathrm{~kg} \mathrm{~m}^{-3}$. Lowest values were reported for deserts and boreal forest with a maximum reported $R D$ less than $4 \mathrm{~kg} \mathrm{~km}^{-3}$. This large spatial variability in $R D$ is induced by climatic factors (Schenk and Jackson, 2002) as they influence the soil water content and the soil temperature which influences biochemical processes within the plant roots (e.g. Kaspar and Bland, 1992; Pierret et al., 2007a). Also specific topographic conditions can induce differences in root characteristics. Significantly higher root tensile strengths were found by Hales et al. (2009) in areas with a divergent topography compared to convergent areas which could be attributed to differences in cellulose 
content due to contrasting soil water potentials. Root systems on steep soils are often asymmetric with stronger roots in uphill direction (Schiechtl, 1980; Chiatante et al., 2003). Small-scale topographic changes induced by root growth itself can also be important to consider as they can reduce soil erosion rates by trapping sediments and organic debris thereby decreasing the sediment transport capacity (Poeppl et al., 2012).

Soil characteristics in turn will also influence root characteristics and as a consequence the erosionreducing potential of plant roots (Fig. 2). De Baets et al. (2007a) observed a negative effect of sand content on the erosion-reducing potential of fibrous roots which can be explained by weaker root-soil bonds in sandy soils and a smaller soil aggregate stability (Pohl et al., 2009). Also a high soil dry bulk density can reduce the erosion-reducing effects of plant roots (De Baets et al., 2007a). Root growth is hampered by an increase in soil bulk density as it influences root penetration in the soil matrix (Chen and Weil, 2009). Alameda and Villar (2012) showed a decrease of roots $<0.5 \mathrm{~mm}$ and an increase of roots > $0.5 \mathrm{~mm}$ with increasing soil bulk density leading to a decrease of $R L D$ and thus the erosion-reducing potential.

Also management practices are important to consider (Fig. 2). Management practices that increase $R D$ or $R L D$ are often used as measures to protect soils against concentrated flow erosion. Multiple sowing practices can be used to increase seedling densities and thus root densities (Gyssels et al., 2002, 2006). Fertilization will affect the nutrient content of the soil and affect root growth as roots prefer locations where nutrients are easily available (e.g. Hodge et al., 2004; Pierret et al., 2007a). Himmelbauer et al. (2013) observed an increase in root density with increasing fertilization rate. However, care has to be taken as fertilization measures in the field can induce shifts in plant species due to changes in soil characteristics, especially in nutrient composition which in turn can change root characteristics (Głąb and Kacorzyk, 2011). The differences in root characteristics for different plant species can be used as an opportunity to select the most appropriate plant species or species compositions to establish within restoration programs (e.g. De Baets et al., 2007b, 2008a; Wang et al., 2014). Finally, one has to account for the temporal variability in root morphological properties and soil characteristics (e.g. Knapen et al., 
2007a; Pollen, 2007; Zhang et al., 2009; Wang et al., 2013). In early growth stages, the above-ground biomass as well as the root systems are not fully developed and soils may be still vulnerable to erosion processes (e.g. Gyssels and Poesen, 2003; Zhou and Shangguan, 2007, 2008; Yu et al., 2014).

As a result, the soil erodibility $(K)$ is directly and indirectly influenced by root and soil characteristics due to their mutual interactions (Fig. 2). Both factors are therefore important to consider when evaluating the erosion-reducing potential of plant roots.

\section{Quantifying the erosion-reducing potential of root systems: methodology}

\subsection{Data collection and standardization}

To explore the overall trends in soil erosion rates as a function of $R D$ and $R L D$ an integrated analysis of published data was made. Data was collected from case studies listed in Table 1 meeting the following criteria: i) the study investigated concentrated flow erosion rates (i.e. rill or gully erosion); ii) the study provides quantitative measurements of soil loss rates in relation to $R D$ or $R L D$ and iii) the study allows estimating the soil detachment ratio $(S D R)$ corresponding to each $R D$ or $R L D$ in an accurate way (see further). Table 2 gives an overview of the selected studies together with information on the studied plant species, the corresponding root architecture, the range in $R D$ or $R L D$, the root sampling area the soil texture and the used flow shear stresses in case of hydraulic flume tests. The majority of data was derived from hydraulic flume tests (Table 1,2). In those experiments the above-ground vegetation is clipped at the soil surface to exclude the effects of the above-ground biomass on the erosion-reducing potential. Also soil properties such as soil moisture, soil chemistry and soil texture are controlled in most experiments to make sure that differences in soil detachment rates can (as much as possible) directly be attributed to root properties.

If the original data was not available, data was digitized from published graphs, using the open source software Engauge Digitizer (v4.1; http://digitizer.sourceforge.net). To compare the data derived from the different studies the soil detachment ratio $(S D R)$ was used. The $S D R$ is the ratio between the absolute soil detachment rate $(A S D)$ for a soil sample with roots and the $A S D$ for a corresponding soil sample without 
roots, i.e. the reference value. $S D R$ values near 0 indicate that erosion is almost completely reduced due to the presence of roots while $S D R$ values near 1 indicate no erosion reduction (De Baets et al., 2006). If no $S D R$ values were mentioned the reported soil erosion rates were converted to $S D R$ values based on a reference value which could be obtained in two ways. If a regression between $R D, R L D$ and the erosion variable was reported (Table 1) the intersection of the regression line with the y-axis was used as reference. In other cases the value corresponding to the smallest reported $R D$ or $R L D$ was used. Studies for which no reliable reference value could be determined (and hence no accurate SDR values) were not further considered. The standardized data from the different empirical studies were pooled in a global dataset on the effect of $R D$ and $R L D$ on $S D R$. Also information on the root architecture (i.e. fibrous or tap roots) and soil texture (i.e. \% sand, \% silt, \% clay) was collected (Table 2). Other potentially relevant factors (e.g. root diameter, soil shear strength, soil organic content) could not be considered as they were not consistently reported in the experimental studies listed in table 2.

\subsection{Statistical analysis}

The relationship between $R D$ or $R L D$ and $S D R$ was analyzed using a non-linear regression approach. Two pre-defined mathematical equations were applied to the datasets as they were proposed in literature: an exponential model (Eq. 2) and the Hill curve model (Hill, 1910; Eq. 3):

$$
\begin{aligned}
& S D R=e^{-b * R(L) D} \\
& S D R=\frac{R(L) D^{-b}}{c+R(L) D^{-b}}
\end{aligned}
$$

The exponential model is most frequent reported in literature (e.g. Mamo and Bubenzer, 2001a,b; De Baets et al., 2006; Shit and Maiti, 2012; Zhang et al., 2013). The exponent $b$ in Eq. 2 represents the rate of decrease in $S D R$ with increasing $R D$ or $R L D$ and can be used to compare the effectiveness of different plant species to reduce erosion (Gyssels et al., 2005). The Hill curve model was also proposed to describe the relationship between root variables and erosion rates (e.g. Li et al., 1991; De Baets et al., 2006; 
Gyssels et al., 2006). This model is a variation of the power model (see numerator and denominator of Eq. 3). However, the power model was omitted in this study as it has an infinite SDR if no roots are present whereas the Hill curve converges to 1 if $R(L) D=0$, as does the exponential model.

In a first step all observations were considered in order to estimate the model parameters of Eq. 2 and Eq. 3. The coefficient of determination $M E$ (Nash and Sutcliffe, 1970) and the relative root mean square error (RRMSE) were calculated to determine the prediction accuracy of the models:

$M E=1-\left(\frac{\sum_{i=1}^{n}\left(O_{i}-P_{i}\right)^{2}}{\sum_{i=1}^{n}\left(O_{i}-\bar{O}\right)^{2}}\right)$

$R R M S E=\frac{\sqrt{\frac{1}{n} \sum_{i=1}^{n}\left(O_{i}-P_{i}\right)^{2}}}{\frac{1}{n} \sum_{i=1}^{n} O_{i}}$

where $O_{i}$ are the observed values, $\bar{O}$ is the observed mean, $P_{i}$ are the predicted values, $n$ is the number of observations. $M E$ values can range from $-\infty$ to 1 . The closer $M E$ is to 1 , the more efficient the model is while negative $M E$ values indicate that the mean observed value is better to describe the trend compared to the model predictions. The smaller the RRMSE value, the more accurate the model.

Secondly, to validate the regression results, the collected data were randomly divided into a calibration and a validation dataset containing respectively three quarters and one quarter of the data. The same nonlinear regression approach was applied to the calibration dataset and results where validated based on the validation dataset. For a reliable validation, this step was repeated 5000 times resulting in a range of possible $M E$ and $R R M S E$ values for both calibration and validation datasets.

\section{Quantifying the erosion-reducing potential of root systems: results of the meta-analysis}

\subsection{Effects of root density $(R D)$ and root length density ( $R L D)$ on soil detachment ratios (SDR)}

Fig. 3 shows the plots of the global datasets on the relation between $R D, R L D$ and $S D R$. For $R D, 822$ data observations were derived from 13 empirical studies whereas only 274 data observations could be derived for $R L D$ from 6 empirical studies (Table 2). $S D R$ values above 1.5 were not plotted in Fig.3 for readability 
reasons but were taken into account in the analysis. The smaller number of observations for $R L D$ compared to $R D$ can be attributed to the fact that measuring $R L D$ is more time-consuming compared to $R D$ (Smit et al., 2000).

Observed $R D$ values range from $0.004 \mathrm{~kg} \mathrm{~m}^{-3}$ to $38.7 \mathrm{~kg} \mathrm{~m}^{-3}$ whereas the range of $R L D$ is from $0.35 \mathrm{~km} \mathrm{~m}^{-}$ ${ }^{3}$ to $6228.8 \mathrm{~km} \mathrm{~m}^{-3}$. For $S D R$, values range from 0.0008 to 3.84 for $R D$ and from 0.0011 to 2.87 for $R L D$. $S R D$ values exceeding 1 indicate an increase in the soil erosion rate due to the presence of roots compared to a rootless soil. This was mainly the case for tap root systems and could be partially attributed to the effect of vortex erosion (Poesen et al., 1994) that scours the topsoil around tap roots sticking out of the ground (De Baets et al., 2007a). Overall, by modifying the mechanical properties of the soil, plant roots are able to decrease $S D R$ by more than $70 \%$ for $0<R D<10 \mathrm{~kg} \mathrm{~m}^{-3}$ and $0<R L D<130 \mathrm{~km} \mathrm{~m}^{-3}$. It should be noticed that the data presented in Fig. 3 mainly took into account the short-term effects of plant roots on the mechanical properties of the soil as only few studies evaluated root-permeated soil samples older than a few months (i.e. Li and Li, 2011; Shit and Maiti, 2012; Wang et al., 2013,2014).

Results of the non-linear regression analysis for $R D$ and $R L D$ are summarized in Table 3 . Higher $M E$ values could be observed for the Hill curve models compared to the exponential models. Also RRMSE values are lower for the Hill curve models compared to those for the exponential models. Based on these results the Hill curve is selected as best fit between $R D, R L D$ and $S D R$ (Fig. 3).

$$
\begin{array}{ll}
S D R=\frac{R D^{-0.35}}{1.78+R D^{-0.35}} & (M E=0.11, \mathrm{n}=822) \\
S D R=\frac{R L D^{-0.46}}{0.56+R L D^{-0.46}} & (M E=0.17, \mathrm{n}=274)
\end{array}
$$

It should be noticed that both Hill curve models have a low predictive accuracy with model efficiencies of 0.11 and 0.17 for $R D$ and $R L D$ respectively and $R R M S E$ values of 1.17 and 0.96 for $R D$ and $R L D$ respectively (Table 3). These values are comparable to the median $M E$ values observed when using calibration and validation datasets (Table 4). However large ranges of $M E$ and RRMSE values could be observed especially for the validation datasets. This indicates that model results are less robust as a result 
of the large variability in the datasets that remains unexplained (Fig. 3). A large source of variability in $S D R$ is inherently linked to the data sampling, as data is pooled from various empirical studies, representing different i) plant species and thus root characteristics, ii) soil characteristics and iii) experimental set-ups to evaluate the erosion-reducing effects of plant roots. Nonetheless, the positive MEvalues indicate that the models are better to predict the general trend in the data compared to the mean trend. Such low ME-values are not unique for this study and recur in several studies aiming to simulate soil erosion rates, catchment sediment export or other geomorphic processes (e.g. de Vente et al., 2013). Furthermore the observed low ME-values are to a certain degree the result of the large scatter in the data especially when only few roots are present (i.e. low RD and RLD values, Fig. 3). Once there is a decent amount of roots present, the positive effect of roots on erosion reduction is more pronounced and the models fit closer to the data (see Section 4.3). To deal with those low ME-values, an attempt was made to increase the reliability of the estimations of the root effects on soil erosion rates by 1) taking into account additional variables (Section 4.2) and by 2) taking into account explicitly the uncertainty levels induced by the unexplained variability (Section 4.3).

\subsection{Effects of root architecture and soil texture on the erosion-reducing potential of roots}

An attempt was made to improve the Hill curve models by taking into account additional information on root architecture and soil texture as those variables were consistently reported in most studies. First, the influence of root architecture on the erosion-reducing potential of plant roots was analyzed by dividing the global datasets for $R D$ and $R L D$ in subsets according to the root type, i.e. fibrous or tap root systems. Secondly, the resulting subsets were further divided based on soil texture: i.e. sandy soils containing more than $50 \%$ sand and non-sandy soils containing less than $50 \%$ sand. This enables us to test whether the hypothesis is valid that plant roots are less effective in reducing soil erosion rates in sandy soils (De Baets et al., 2007a).

Results of the non-linear regression analyses for these subsets of the global datasets for $R D$ and $R L D$ are summarized in Table 5. For $R D$, taking into account root architecture yielded a negligible improvement in 
model efficiency for fibrous roots $(M E=0.13)$ while a decline in model efficiency could be observed for tap roots $(M E=0.07)$ (Fig. 4). The fact that there is no improvement can be explained by the large variability within each root system class itself (Fig. 3). This results in large ranges for possible $M E$ and RRMSE for the calibration and validation datasets indicating that the models are not robust and still a large part of variability remains unexplained. For $R L D$, only a significant model was found for fibrous root systems while no relationship could be found for tap root systems (Table 5). A significant improvement of model efficiency $(M E=0.27)$ was observed for fibrous root systems (Eq. 8) compared to results of the global dataset (Fig. 4). Despite the improvement in $M E$, still a large part of the variability cannot be explained by $R L D$ and root architecture only. Also the large range of $M E$ and $R R M S E$ values in the calibration and validation results still indicates a low overall accuracy (Table 6).

$S D R=\frac{R L D^{-0.66}}{0.34+R L D^{-0.66}} \quad(M E=0.27, n=133 ;$ fibrous roots, all soil types $)$

Comparison of the parameter estimates of the Hill curves for both $R D$ and $R L D$ showed that estimated bvalues for fibrous root systems are larger compared to tap root systems resulting in a stronger decrease in $S D R$ with increasing $R D$ and $R L D$ (Fig. 4). This confirms that, in general, fibrous roots are more effective in controlling erosion due to concentrated flow compared to tap roots (Section 2).

Next to root architecture, also soil texture was taken into account. In case of $R D$ a significant improvement could be observed in model efficiency for fibrous roots in sandy soils (sand content $>50 \%$ ) with $M E=$ 0.67 and RRMSE $=0.61$ (Table 5). Other regression results for $R D$ yielded no improvement or were not significant in the case of tap root systems in non-sandy soils. The regression results for fibrous roots in sandy soils have to be interpreted with care because those data are to some extent biased as they originate from only 2 studies (De Baets and Poesen, 2010; Shit and Maiti, 2012).

Due to the low number of observations a large part of the variability is excluded that could be induced by differences in soil and root characteristics among studies, and hence an extrapolation to other areas will 
not be reliable. Therefore only significant Hill curves for non-sandy soils are represented in Fig. 4. For $R D$ only the Hill curve for fibrous roots in non-sandy soils is plotted which is almost similar to the Hill curve model based on the global dataset and the subset based on fibrous roots. For $R L D$, only regression results for fibrous roots in non-sandy soils were significant and yielded a significant improvement with $M E=$ 0.37 (Eq. 9; Table 5). It should be mentioned that the number of observations within the subsets decreases which in turn reduces the variability. This explains to some extent the higher $M E$. However RRMSE values were not significantly smaller and still a large part of unexplained variance exists (Table 5).

$S D R=\frac{R L D^{-0.94}}{0.20+R L D^{-0.94}} \quad(M E=0.37, n=109 ;$ fibrous roots, non-sandy soils $)$

Due to the small number of data for sandy soils compared to non-sandy soils, a comparison of the erosionreducing potential of plant roots in sandy and non-sandy soils is hard to make. In case of $R D$, higher $\mathrm{b}$ values could be observed for sandy soils compared to non-sandy soils for both fibrous and tap root systems indicating a positive effect of the sand content on the erosion-reducing potential of plant roots. This contrasts with the results of De Baets and Poesen (2010) who reported a negative effect of sand content on the erosion-reducing effect of plant roots. However, no conclusive evidence can be found as the now available data for sandy soils only yield a limited number of observations (Table 5). Additional data for different soil textures is needed to unravel the soil texture effect on the erosion-reducing effects of plant roots.

When compiling data from different sources one has to be aware of the effects of auto-correlation effects among variables. A detailed analysis of those effects was, however, not possible as only few additional variables (i.e. root architecture and soil texture) were thoroughly reported in all studies. Nonetheless autocorrelation effects could possibly contribute to the unexplained variance of the models.

\subsection{Assessment of uncertainty ranges on the erosion-reducing potential of plant roots}


Despite the attempt to increase the model efficiency by including root architecture and soil texture, only a limited improvement could be observed (Section 2.2). Based on the proposed models, it is still very difficult to predict the effects of plant roots on concentrated flow erosion rates. To allow meaningful estimations of the erosion-reducing effects of plant roots based on the proposed models, the uncertainty has to be taken into account. This was done by means of a Monte Carlo simulation. In a first step the cumulative distribution function (cdf) of the relative residues (i.e. the observed SDR divided by the predicted $S D R$ ) was determined. The residues could be best described by means of an exponential distribution which was further used to generate random residues. The uncertainty range on predicted SDR values was estimated for $R D$ ranging from 0 to $40 \mathrm{~kg} \mathrm{~m}^{-3}$ in steps of $0.1 \mathrm{~kg} \mathrm{~m}^{-3}$ and $R L D$ ranging from 0 to $1000 \mathrm{~km} \mathrm{~m}^{-3}$ in steps of $1 \mathrm{~km} \mathrm{~m}^{-3}$. For each $R D$ or $R L D$ the corresponding $S D R$ value was calculated based on the derived Hill curve model which was then multiplied by a random residue generated from the derived exponential distribution. This step was repeated 10000 simulations for each $R D$ and $R L D$. Finally the $95 \%$ quantile was determined based on the 10000 simulations for every $R D$ and $R L D$.

The resulting 95\% confidence intervals of the estimated SDR values are represented in Fig. 5 together with the proposed Hill curve models. For a meaningful assessment of the erosion-reducing potential, the uncertainty range, which can be derived from the plots in Fig. 5, has to taken in to account. The upper level of this range should than be interpreted as the minimal root effect that can be expected. Fig. 5 indicates threshold values for $R D$ and $R L D$ which has to be reached in order to have an erosion-reducing effect at $95 \%$ confidence interval, i.e. the corresponding $R D$ or $R L D$ at which the upper boundary of the 95\% confidence interval falls below $S D R=1.0$.

For $R D$, similar uncertainty ranges could be observed for Hill curve models based on the global dataset and the subset based on fibrous roots with a threshold value for both models of $1.3 \mathrm{~kg} \mathrm{~m}^{-3}$ (Fig. 5). For tap roots system a larger uncertainty exists on predicted SDR values and hence a higher threshold value of 13 $\mathrm{kg} \mathrm{m}^{-3}$. Based on these results together with the regression results we propose to use the established model based on all observations (Eq. 6) to estimate the potential erosion-reducing effects of plant roots. The uncertainty on the predicted $S D R$ values can be derived from Fig. 5. For $R L D$, uncertainty ranges are 
shown in Fig. 5 for the three significant Hill curve models (Section 4.2). Similar threshold values were found for the three models ranging between 13 and $18 \mathrm{~km} \mathrm{~m}^{-3}$ however uncertainty ranges on predicted $S D R$ values are decreasing when taking into account more controlling factors (Fig. 5). Therefore, in case of plant species with fibrous root systems, Eq. 8 can be used to estimate the erosion-reducing potential irrespective of the soil texture. In case of non-sandy soils ( $<50 \%$ sand), Eq. 9 is proposed.

Overall we prefer the use of models based on $R L D$ to those based on $R D$ as uncertainty ranges are smaller for $R L D$ compared to $R D$. In addition, $R L D$ is indirectly correlated to root architecture while this is not the case for $R D$. A soil containing a certain amount of roots (expressed as $R D$ ) will have a much larger $R L D$ in the case of a fibrous root system (consisting of many fine roots) compared to a tap root system consisting of a thick central tap root. This can be observed in Fig. 3 and is confirmed by means of a Kruskal-Wallis test $\left(\chi^{2}=72.99, p=<2.2 \mathrm{e}-16\right)$ indicating significant larger $R L D$ values for fibrous root systems, while no significant differences between fibrous and tap roots could be observed for $R D$ measures. This is a mayor disadvantage when using $R D$ as root variable to estimate $S D R$ values as a soil can have a high $R D$ but a low $R L D$ in case of tap roots. As a result an overestimation of the erosion-reducing potential will be made when using $R D$ as root variable. This is in accordance with the hydraulic flume results of Burylo et al. (2012) who found no significant correlation between $R D$ and $S D R$ for three tested plant species while the percentage fine roots $(<0.5 \mathrm{~mm})$ were significantly correlated to $S D R$ and $R L D$. In order to use $R D$ to estimate the erosion-reducing potential, root diameter can be used as additional variable to account for root architecture as it was significantly and positively related to SDR (Burylo et al., 2012). This is in line with the results of De Baets et al. (2007a) and De Baets and Poesen (2010) who found a negative influence of root diameter on the erosion-reducing effect. An analysis of the effect of root diameter in this study was not possible due to the lack of sufficient data reported in the literature.

\section{Conclusions}

Vegetation can be used to reduce soil degradation by soil erosion processes. This study showed that plant roots can be very effective in controlling soil erosion rates due to concentrated flow. A combination of a 
well-established vegetation cover together with a dense root system in the topsoil is therefore most effective and recommended to protect the soil against soil erosion processes by water. The erosionreducing potential of plant roots can be explained by their indirect negative effect on soil erodibility through affecting various soil properties (e.g. aggregate stability, cohesion, organic matter content, infiltration rate and moisture content). However both the environment and management practices have to be taken into account as they influence the effectiveness of plant roots in reducing soil erosion rates. Analysis of a global dataset based on published data showed that the decrease in $S D R$ as a function of $R D$ or $R L D$ could be best described by a Hill curve model. Root architecture and soil texture were further considered as an attempt to improve the models. This resulted in better predictive models for $R L D$ (for fibrous roots in non-sandy soils) while no improvement could be observed for $R D$. Consequently, it remains difficult to predict the erosion-reducing effects of plant roots on concentrated flow erosion rates as still a large part of the variance remains unexplained. Results of the Monte Carlo analyses (Fig. 5) present confidence intervals on estimated SDR values for the proposed models that should be used as a estimation of the uncertainty range. As such, the established relationships between root (length) density and the soil detachment ratio allow for meaningful estimations of the mechanical effects of plant roots on concentrated flow erosion rates. The advantage of this approach is that the results of this study can be extrapolated to different environments to examine the likely root effects on erosion rates, as we implicitly take into account the variability in root and soil characteristics.

As tap root systems are less effective in controlling soil erosion compared to fibrous roots, we furthermore prefer the use of $R L D$ as root variable as it indirectly takes into account the root architecture. The influence of soil texture on erosion-reducing potential could not be demonstrated due to a lack of sufficient data on the erosion-reducing potential of plant roots in different soil textures. More empirical studies are needed to examine the role of soil texture on the erosion-reducing potential. Moreover, a more accurate global database is needed to unravel the influence of additional soil, root and environmental variables on the erosion-reducing potential of plant roots and to improve the predictive quality of the models. 


\section{Acknowledgements}

M. Vanmaercke acknowledges a postdoctoral research grant from the Research Foundation Flanders (FWO), Brussels, Belgium. We thank the anonymous reviewers for their constructive comments.

\section{References:}

Abiven, S., Menasseri, S., Chenu, C. (2009). The effects of organic inputs over time on soil aggregate stability - A literature analysis. Soil Biology \& Biochemistry 41: 1-12.

Alameda, D., Villar, R. (2012). Linking root traits to plant physiology and growth in Fraxinus angustifolia Vahl. seedlings under soil compaction conditions. Environmental and Experimental Botany 79: 49-57. Amézketa, E. (1999). Soil aggregate stability: a review. Journal of Sustainable Agriculture 14: 83-151.

Angers, D., Caron, J. (1998). Plant-induced changes in soil structure: processes and feedbacks. Biogeochemistry 42: 55-72.

Archer, N., Hess, T., Quinton, J. (2002). Belowground relationships of soil texture, roots and hydraulic conductivity in two-phase mosaic vegetation in South-east Spain. Journal of Arid Environments 52: 535-553.

Blanco, H., Lal, R. (2008). Principles of soil conservation and management. Springer, Dordrecht, London, pp. 617.

Bochet, E., Román, A., De Baets, S., Poesen, J. (2012). Root characteristics of two Mediterranean shrubs and their erosion-reducing potential during concentrated flow. $3^{\text {rd }}$ International Conference on Soil Bio- and Eco-Engineering. The use of vegetation to improve soil stability. University of British Columbia, Vancouver, Canada, 23-27 July 2012. Poster, Book of Abstracts pp. 19.

Borcelli, L., Torri, D., Poesen, J., Iaquinta, P. (2012). A robust algorithm for estimating soil erodibility in different climates. Catena 97: 85-94.

Bui, E.N., Box, J.E.J. (1993). Growing corn root effects on interrill soil erosion. Soil Science Society of America Journal 57: 1066-1070. 
Bronick, C.J., Lal, R. (2005). Soil structure and management: a review. Geoderma 124: 3-22.

Burylo, M., Hudek, C., Rey, F. (2012). Plant root traits affecting the resistance of soils to concentrated flow erosion. Earth Surface Processes and Landforms 37: 1463-1470.

Burylo, M., Dutoit, T., Rey, F. (2014). Species traits as practical tools for ecological restoration of marly eroded lands. Restoration ecology 22 (5): 633-640.

Cannon, W.A. (1949). A tentative classification of root systems. Ecology 30: 452-458.

Chen, G., Weil, R.R. (2009). Penetration of cover crop roots through compacted soils. Plant Soil 331(1/2): $31-44$.

Chiatante, D., Scippa, S.G., Di Iorio, A., Sarnataro, M. (2003). The influence of steep slopes on root system development. Plant Growth Regulation 21: 247-260.

Cogo, N.P., Streck, E.V. (2003). Surface and subsurface decomposition of a desiccated grass pasture biomass related to erosion and its prediction with RUSLE. Revista Brasileira de Ciência do Solo 27 (1): $153-164$.

De Baets, S., Poesen, J., Gyssels, G., Knapen, A. (2006). Effects of grass roots on the erodibility of topsoils during concentrated flow. Geomorphology 76: 54-67.

De Baets, S., Poesen, J., Knapen, A., Galindo, P. (2007a). Impact of root architecture on the erosionreducing potential of roots during concentrated flow. Earth Surface Processes and Landforms 32: 13231345.

De Baets, S., Poesen, J., Knapen, A., Barberá, G.G., Navarro, J.A. (2007b). Root characteristics of representative Mediterranean plant species and their erosion-reducing potential during concentrated runoff. Plant Soil 294: 169-183.

De Baets, S., Poesen, J., Reubens, B., Wemans, K., De Baerdemaeker, J., Muys, B. (2008a). Root tensile strength and root distribution of typical Mediterranean plant species and their contribution to soil shear strength. Plant Soil 305: 207-226.

De Baets, S., Torri, D., Poesen, J., Salvador, M.P., Meersmans, J. (2008b). Modelling increased soil cohesion due to roots with EUROSEM. Earth Surface Processes and Landforms 33: 1948-1963. 
De Baets, S., Poesen, J., Reubens, B., Muys, B., De Baerdemaeker, J., Meersmans, J. (2009). Methodological framework to select plant species for controlling rill and gully erosion: application to a Mediterranean ecosystem. Earth Surface Processes and Landforms 34: 1374-1392.

De Baets, S., Poesen, J. (2010). Empirical models for predicting the erosion-reducing effects of plant roots during concentrated flow erosion. Geomorphology 118: 425-432.

De Baets, S., Poesen, J., Meersmans, J., Serlet, L. (2011). Cover crops and their erosion-reducing effects during concentrated flow erosion. Catena 85: 237-244.

de Vente, J., Poesen, J. (2005). Predicting soil erosion and sediment yield at the basin scale: Scale issues and semi-quantitative models. Earth-Science Reviews 71: 95-125.

de Vente, J., Poesen, J., Verstraeten, G., Govers, G., Vanmaercke, M., Van Rompaey, A., Arabkhedri, M., Boix-Fayos, C. (2013). Predicting soil erosion and sediment yield at regional scales: Where do we stand? Earth-Science Reviews 127: 16-29.

Du, Q., Zhong, Q., Wang, K. (2010). Root effect of three vegetation types on shoreline stabilization on Chongming Island, Shanghai. Pedosphere 20 (6): 692-701.

Eshel, A., Beeckman, T. (Eds.) (2013). Plant roots: the hidden half, CRC press, Florida, USA, pp. 848.

Eviner, V.T., Chapin, F.S. (2003). Functional matrix: A conceptual framework for predicting multiple plant effects on ecosystem processes. Annual Review of Ecology, Evolution and Systematics 34: 455485.

Fattet, M., Fu, Y., Ghestem, M., Ma, W., Foulonneau, M., Nespoulous, J., Le Bissonnais, Y., Stokes, A. (2011). Effects of vegetation type on soil resistance to erosion: Relationship between aggregate stability and shear strength. Catena 87: 60-69.

Fitter, A.H. (1987). An architectural approach to the comparative ecology of plant root systems. The New Phytologist 106(Suppl.): 61-77.

Genet, M., Stokes, A., Salin, F.S.B., Fourcaud, T., Dumail, J., van Beek, R. (2005). The influence of cellulose content on tensile strength in tree roots. Plant Soil 278: 1-9. 
Ghidey, F., Alberts, E.E. (1997). Plant root effects on soil erodibility, splash detachment, soil strength, and aggregate stability. Transactions of the American Society of Agricultural Engineers 40: 129-135.

Głąb, T., Kacorzyk, P. (2011). Root distribution and herbage production under different management regimes of mountain grassland. Soil \& Tillage Research 113: 99-104.

Gray, D.H., Leiser, A.T. (1982). Biotechnical slope protection and erosion control. Van Nostrand Reinhold Company, New York, pp. 271.

Gregory, P.J. (2006). Plant roots: growth, activity and interaction with soils. Blackwell Publishing, Oxford, pp. 318.

Gumiere, S.J., Le Bissonnais, Y, Raclot, D., Cheviron, B. (2011). Vegetated filter effects on sedimentological connectivity of agricultural catchments in erosion modeling: A review. Earth Surface Processes and Landforms 36: 3-19.

Gyssels, G., Poesen, J., Nachtergaele, J., Govers, G. (2002). The impact of sowing density of small grains on rill and ephemeral gully erosion in concentrated flow zones. Soil \& Tillage Research 64: 189-201.

Gyssels, G., Poesen, J. (2003). The importance of plant root characteristics in controlling concentrated flow erosion rates. Earth Surface Processes and Landforms 28: 371-384.

Gyssels, G., Poesen, J., Bochet, E., Li, Y. (2005). Impact of plant root characteristics on the resistance of soils to erosion by water: a review. Progress in Physical Geography 29 (2): 189-217.

Gyssels, G., Poesen, J., Liu, G., Van Dessel, W., Knapen, A., De Baets, S. (2006). Effects of cereal roots on detachment rates of single- and double-drilled topsoils during concentrated flow. European Journal of Soil Science 57: 381-391.

Hales, T.C., Ford, C.R., Hwang, T., Vose, J.M., Band, L.E. (2009). Topographic and ecologic controls on root reinforcement. Journal of Geophysical Research 114: F03013 doi:10.1029/2008JF001168.

Hill, A.V. (1910). The possible effects of the aggregation of the molecules of haemoglobin on its dissociation curves. Journal of Physiology 40: 4-7. 
Himmelbauer, M.L., Vateva, V., Lozanova, L., Loiskandl, W., Rousseva, S. (2013). Site effects on root characteristics and soil protection capability of two cover crops grown in South Bulgaria. Journal of Hydrology and Hydromechanics 61: 30-38.

Hodge, A. (2004). The plastic plant: root responses to heterogeneous supplies of nutrients. New Phytologist 162: 9-24.

Hoffmans, G. Akkerman, G.J., Verheij, H., van Hoven, A., van der Meer, J. (2008). The erodibility of grassed inner dike slopes against wave overtopping. In: American Society of Civil Engineers (Ed.) Proceedings of $31^{\text {st }}$ Conference on Coastal Engineering, Hamburg, Germany, pp. 2957-2969.

IPCC 2013 Climate Change 2013: The Physical Science Basis. Working Group I Contribution to the Intergovernmental Panel on Climate Change Fifth Assessment Report (Cambridge: Cambridge University Press).

Jackson, R.B., Canadell, J., Ehleringer, J.R., Mooney, H.A., Sala, O.E., Schulze, E.D. (1996). A global analysis of root distribution for terrestrial biomes. Oecologia 108: 389-411.

Jastrow, J.D., Miller, R.M., Lussenhop, J. (1998). Contributions of interacting biological mechanisms to soil aggregate stabilization in restored prairie. Soil Biology and Biochemistry 30 (7): 905-916.

Johnson, N.C., Gehring, C.A. (2007). Mycorrhizas: symbiotic mediators of rhizosphere and ecosystem processes. In: Cardon, Z.G., Whitbeck, J.L. (Eds.) (2007). The rhizosphere. An ecological perspective. Elsevier Academic Press, New York, USA, pp. 212.

Jones, D.L., Nguyen, C., Finlay, R.D. (2009). Carbon flow in the rhizosphere: carbon trading at the soilroot interface. Plant Soil 325: 5-33.

Kaspar, T.C., Bland, W.L., (1992). Soil temperature and root growth. Soil Science 154 (4): 290-299.

Katuwal, S., Vermang, J., Cornelis, W.M., Gabriels, D., Moldrup, P., de Jonge, L.W. (2013). Effect of root density on erosion and erodibility of a loamy soil under simulated rain. Soil Science 178: 1-8.

Kinell, P.I.A. (1993). Runoff as a factor influencing experimentally determined interrill erodibilities. Australian Journal of Soil Research 31(3): 333-342. 
Knapen, A., Poesen, J., De Baets, S. (2007a). Seasonal variations in soil erosion resistance during concentrated flow for a loess-derived soil under two contrasting tillage practices. Soil \& Tillage Research 94: 425-440.

Knapen, A, Poesen, J. Govers, G., Gyssels, G., Nachtergaele, J. (2007b). Resistance of soils to concentrated flow erosion: A review. Earth-Science Reviews 80: 75-109.

Knapen, A., Poesen, J. (2010). Soil erosion resistance effects on rill and gully initiation points and dimensions. Earth surface processes and landforms 35: 217-228.

Lane, L.J., Foster, G.R., Nicks, A.O. (1987). Use of fundamental erosion mechanics in erosion prediction. American Society of Agricultural and Biological Engineers Paper No. 87-2540.

Leifheit, E.F., Veresoglou, S.D., Lehmann, A., Morris, E.K., Rillig, M.C. (2014). Multiple factors influence the role of arbuscular Mycorrhizal fungi in soil aggregation - a meta-analysis. Plant Soil 374: 523-537.

Léonard, J., Richard, G. (2004). Estimation of runoff critical shear stress for soil erosion from soil shear strength. Catena 57: 233-249.

Li, Y., Zhu, X.M., Tian, J.Y. (1991). Effectiveness of plant roots to increase the anti-scourability of soil on the Loess Plateau. Chinese science bulletin 36 (24): 2077-2081.

Li, Y., Xu, X.Q., Zhu, X.M., Tian, J.Y. (1992). Effectiveness of plant roots on increasing the soil permeability on the loess plateau. Chinese science bulletin 37 (20): 1735-1738.

Li, P., Li, Z. (2011). Soil reinforcement by a root system and its effects on sediment yield in response to concentrated flow in the loess plateau. Agricultural Sciences 2 (2): 86-93.

Li, Y., Yu, H.Q., Zhou, N., Tian, G., Poesen, J., Zhang, Z.D. (2015). Linking fine root and understory vegetation to channel erosion in forested hillslopes of southwestern China. Plant Soil 389: 323-334.

Liu, G., Huang, C., Hickman, M.V., (2005). Effects of plant roots on soil detachment by runoff. (Unpublished manuscript).

Maetens, W., Poesen, J., Vanmaercke, M. (2012). How effective are soil conservation techniques in reducing plot runoff and soil loss in Europe and the Mediterranean? Earth-Science reviews 115: 21-36. 
Mamo, M., Bubenzer, G.D. (2001a). Detachment rate, soil erodibility, and soil strength as influenced by living plant roots. Part I: Laboratory study. Transactions of the American Society of Agricultural Engineers 44 (5): 1167-1174.

Mamo, M., Bubenzer, G.D. (2001b). Detachment rate, soil erodibility, and soil strength as influenced by living plant roots. Part II: Field study. Transactions of the American Society of Agricultural Engineers 44 (5): 1175-1181.

Mao, Z., Saint-André, L., Genet, M., Mine, F.X., Jourdan, C., Rey, H., Courbaud, B., Stokes, A. (2012). Engineering ecological protection against landslides in diverse mountain forests: choosing cohesion models. Ecological engineering 45: 55-69.

McCully, M.E. (1999). Roots in soil: Unearthing the complexities of roots and their rhizospheres. Annual Review of Plant Physiology and Molecular Biology 50: 695-718.

Meyer, L.D. (1964). Mechanics of soil erosion by rainfall and runoff as influenced by slope length, slope steepness, and particle size. PhD Dissertation, Purdue University, West Lafayette, IN, pp. 161.

Meyer, L.D., Harmon, W.C. (1984). Susceptibility of agricultural soils to interrill erosion. Soil Science Society of America Journal 48(5): 1152-1157.

Moody, J.A., Nyman, P. (2012). Variations in soil detachment rates after wildfire as a function of soil depth, flow properties and root properties. Geological Survey Scientific Investigations Report 20125233, pp. 40.

Montgomery, D.R., Dietrich, W.E. (1994). Landscape dissection and drainage area-slope thresholds Chapter 11. In Kirkby, M.J. (Ed.), Process Models and Theoretical Geomorphology. John Wiley \& Sons Ltd., pp. 221-246.

Morgan, R.P.C., Rickson, R.J. (1995). Slope stabilization and erosion control: a bioengineering approach. Chapman and Hall, London, UK, pp. 274.

Morgan, R.P.C. (2005). Soil erosion \& Conservation. Third edition. Blackwell Publishing, Oxford, pp. 316. 
Mwango, S.B., Msanya, B.M., Mtakwa, P.W., Kimaro, D.N., Deckers, J., Poesen, J., Massawe, V., Bethuel, I. (2014). Root properties of plants used for soil erosion control in the Usambara Mountains, Tanzania. International Journal of Plant \& Soil Science 3 (12): 1567-1580.

Nash, J. E., Sutcliffe, J. V. (1970). River flow forecasting through conceptual models, 1, A discussion of principles, Journal of Hydrology 10 (3): 282-290.

Nearing, M.A., Norton, L.D., Bulgakov, D.A., Larionov, G.A., West, L.T., Dontsova, K.M. (1997). Hydraulics and erosion in eroding rills. Water Resources Research 33(4): 865-876.

Normaniza, O., Barakbah, S.S., (2006). Parameters to predict slope stability - Soil water and root profiles. Ecological engineering 28: 90-95.

Norris, J.E., Stokes, A., Mickovski, S.B., Cammeraat, E., van Beek, R., Nicoll, B.C., Achim, A. (Eds.) (2008). Slope stability and erosion control: ecotechnological solution. Springer, Dordrecht, The Netherlands, pp. 290.

Pierret, A., Doussan, C., Capowiez, Y., Bastardie, F., Pagès, L. (2007a). Root functional architecture: a framework for modeling the interplay between roots and soil. Vadose Zone Journal 6 (2): 269-281.

Pierret, A., Latchackak, K., Chathanvongsa, P., Sengtaheuanghoung, O., Valentin, C. (2007b). Interactions between root growth, slope and soil detachment depending on land use: a case study in a small mountain catchment of Northern Laos. Plant Soil 301: 54-64.

Poeppl, R.E., Keiler, M., Von Elverfeldt, K., Zweimueller, I., Glade, T. (2012). The influence of riparian vegetation cover on diffuse lateral sediment connectivity and biogeomorphic processes in a mediumsized agricultural catchment, Austria. Geografiska Annaler: Series A, Physical Geography 94: 511529.

Poesen, J., Torri, D., Bunte, K. (1994). Effects of rock fragments on soil erosion by water at different spatial scales: a review. Catena 23: 141-166.

Poesen, J., Nachtergaele, J., Verstraeten, G., Valentin, C. (2003). Gully erosion and environmental change: importance and research needs. Catena 50: 91-133. 
Pohl, M., Alig, D., Körner, C., Rixen, C. (2009). Higher plant diversity enhances soil stability in disturbed alpine ecosystems. Plant Soil 324: 91-102.

Pollen, N., Simon, A. (2005). Estimating the mechanical effects of riparian vegetation on stream bank stability using a fiber bundle model. Water Resources Research 41, W07025, doi:10.1029/2004WR003801.

Pollen, N. (2007). Temporal and spatial variability in root reinforcement of streambanks: Accounting for soil shear strength and moisture. Catena 69: 197-205.

Pollen-Bankhead, N., Simon, A. (2010). Hydrologic and hydraulic effects of riparian root networks on streambank stability: Is mechanical root-reinforcement the whole story? Geomorphology 116: 353362.

Quang, T.T., Oumeraci, H. (2012). Numerical modeling of wave overtopping-induced erosion of grassed inner sea-dike slopes. Natural Hazards 63: 417-447.

Reubens, B. Poesen, J., Danjon, F. Geudens, G., Muys, B. (2007). The role of fine and coarse roots in shallow slope stability and soil erosion with a focus on root system architecture: a review. Trees 21: 385-402.

Reubens, B., Moeremans, C., Poesen, J., Nyssen, J., Tewoldeberhan, S., Franzel, S., Deckers, J., Orwa, C., Muys, B. (2011). Tree species selection for land rehabilitation in Ethiopia: from fragmented knowledge to an integrated multi-criteria decision approach. Agroforestry Systems 82: 303-330.

Rey, F. (2003). Influence of vegetation distribution on sediment yield in forested marly gullies. Catena 50: 549-562.

Rey, F., Ballais, J.-L., Marre, A., Rovéra, G. (2004). Rôle de la végétation dans la protection contre l'érosion hydrique de surface. Comptes Rendus Geoscience 336: 991-998.

Schenk, H.J., Jackson, R.B. (2002). The global biogeography of roots. Ecological Monographs 73 (3):311328.

Schiechtl, H.M. (1980). Bioengineering for land reclamation and conservation. University of Alberta Press, Edmonton, Canada, pp. 404. 
Shit, P.K., Maiti, R. (2012). Effects of plant root density on the erodibility of lateritic topsoil by simulated flume experiment. International Journal of Forest, Soil and Erosion 2 (3):137-142.

Sigunga, D.O., Kimura, M., Hoshino, M., Asanuma, S., Onyango, J.C. (2015). Root-fusion characteristics of eucalyptus trees block gully development. International Journal of Forest, Soil and Erosion 5 (1): $32-34$.

Simon, A., Collison, A.J.C. (2002). Quantifying the mechanical and hydrological effects of riparian vegetation on streambank stability. Earth Surface Processes and Landforms 27: 527-546.

Smit, A.L., Bengough, A.G., Engels, C., van Noordwijk, M., Pellerin, S., van de Geijn, S.C. (2000). Root methods, a Handbook. Springer-Verlag, Heidelberg, pp. 594.

Stokes, A., Spanos I., Norris, J.E., Cammeraat E. (Eds.) (2007). Eco- and Ground Bio-Engineering: The Use of Vegetation to Improve Slope Stability, Springer, Dordrecht, The Netherlands, pp. 438.

Stokes, A., Atger, C., Bengough, A.G., Fourcaud, T., Sidle, R.C. (2009). Desirable plant roots traits for protection natural and engineered slopes against landslides. Plant Soil 324: 1-30.

Stokes, A., Douglas, G.B., Fourcaud, T., Giadrossich, F., Gillies, C., Hubble, T., Kim, J.H., Loades, K.W., Mao, Z., McIvor, I.R., Mickovski, S.B., Mitchell, S., Normaniza, O., Phillips, C., Poesen, J., Polster, D., Preti, F., Raymond, P., Rey, F., Schwarz, M., Walker, L.R. (2014). Ecological mitigation of hillslope instability: ten key issues facing researchers and practitioners. Plant Soil 377: 1-23.

Thornes, J.B. (1990). Vegetation and erosion. Processes and environments, Chichester: Wiley. pp. 518.

Torri, D. (1987). A theoretical study of soil erodibility. In: Ahnert, F. (Ed.), Catena Supplement 10: Geomorphological models - Theoretical and empirical aspects, Catena Verlag, Braunschweig, Germany, pp. 15-20.

Torri, D., Poesen, J. (2014). A review of topographic threshold conditions for gully head development in different environments. Earth-Science Reviews 130: 73-85.

Traoré, O., Groleau-Renaud, V., Plantureux, S., Tubeileh, A., Bœf-Tremblay, V. (2000). Effect of root mucilage and modelled root exudates on soil structure. European Journal of Soil Science 51: 575-581. 
Vanmaercke, M., Poesen, J., Verstraeten, G., Maetens, W., de Vente, J. (2011). Sediment yield as a desertification risk indicator. Science of the Total Environment 409: 1715-1725.

Vanmaercke, M., Maetens, W., Poesen, J., Jankauskas, B., Jankauskiene, G., Verstraeten, G., de Vente, J. (2012). A comparison of measured catchment sediment yields with measured and predicted hillslope erosion rates in Europe. Journal of Soils and Sediments 12 (4): 586-602.

Wang, J.G., Li, Z.X., Cai, C.F., Yang, W., Ma, R.M., Zhang, G.B. (2011). Predicting physical equations of soil detachment by simulated concentrated flow in Ultisols (subtropical China). Earth Surface Processes and Landforms 37: 633-641.

Wang, B., Zhang, G.H., Shi, Y.Y., Zhang, X.C., Ren, Z.P., Zhu, L.J. (2013). Effect of natural restoration time of abandoned farmland on soil detachment by overland flow in the Loess Plateau of China. Earth Surface Processes and Landforms 38: 1725-1734.

Wang, B., Zhang, G.H., Shi, Y.Y., Zhang, X.C. (2014). Soil detachment by overland flow under different vegetation restoration models in the Loess Plateau of China. Catena 116: 51-59.

Whalley, W.R., Riseley, B., Leeds-Harrison, P.B., Bird, N.R.A., Leech, P.K., Adderley, W.P. (2005). Structural differences between bulk and rhizosphere soil. European Journal of Soil Science 56: 353360.

Wu, T.H. (1976). Investigation of Landslides on Prince of Wales Island, Alaska. Ohio State University, Department of Civil Engineering, Geotechnical Engineering Report, 5, pp. 93.

Yu, Y.C., Zhang, G.H., Geng, R., Sun, L. (2014). Temporal variation in soil detachment capacity by overland flow under four typical crops in the Loess Plateau of China. Biosystems Engineering 122: 139-148.

Zhang, G.H., Tang, M.K., Zhang, X.C. (2009). Temporal variation in soil detachment under different land uses in the Loess Plateau of China. Earth Surface Processes and Landforms 34: 1302-1309.

Zhang, G., Liu, G., Wang, G. (2012). Effects of canopy and roots of patchy distributed Artemisia capillaris on runoff, sediment, and the spatial variability of soil erosion at the plot scale. Soil Science 177 (6): 409-415. 
Zhang, G., Tang, K., Ren, Z., Zhang, X.C. (2013). Impact of grass root mass density on soil detachment capacity by concentrated flow on steep slopes. Transactions of the American Society of Agricultural and Biological Engineers 56 (3): 927-934.

Zhou, Z.C., Shangguan, Z.P. (2005). Soil anti-scourability enhanced by plant roots. Journal of Integrative Plant Biology 47 (6): 676-682.

Zhou, Z.C., Shangguan, Z.P. (2007). The effects of ryegrass roots and shoots on loess erosion under simulated rainfall. Catena 70: 350-355.

Zhou, Z.C., Shangguan, Z.P. (2008). Effects of ryegrasses on soil runoff and sediment control. Pedosphere 18 (1): 131-136.

Zhu, J.C., Gantzer, C.J., Anderson, S.H., Peyton, R.L., Alberts, E.E. (2001). Comparison of concentratedflow detachment equations for low shear stress. Soil \& Tillage Research 61: 203-212.

Zuazo, V.H.D., Pleguezuelo, C.R.R. (2008). Soil-erosion and runoff prevention by plant covers. A review. Agronomy for sustainable Development 28: 65-68. 


\section{Figures:}

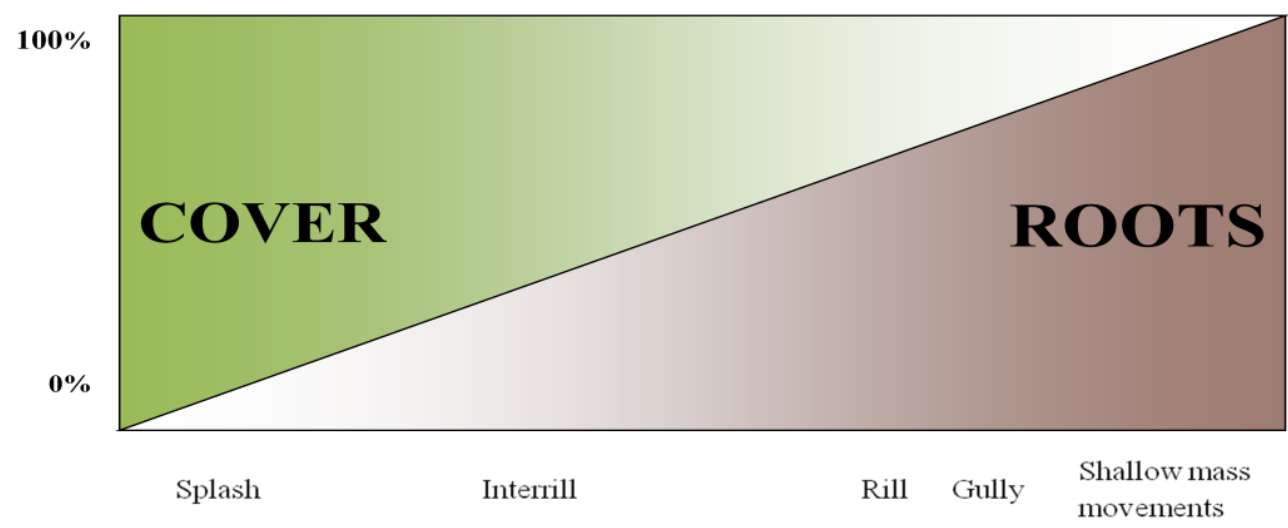

Erosion process

Fig. 1. Structural model of the erosion-reducing potential of vegetation cover and plant roots for different erosion processes by water (Based on Gyssels et al., 2005).

\section{Root growth factors}

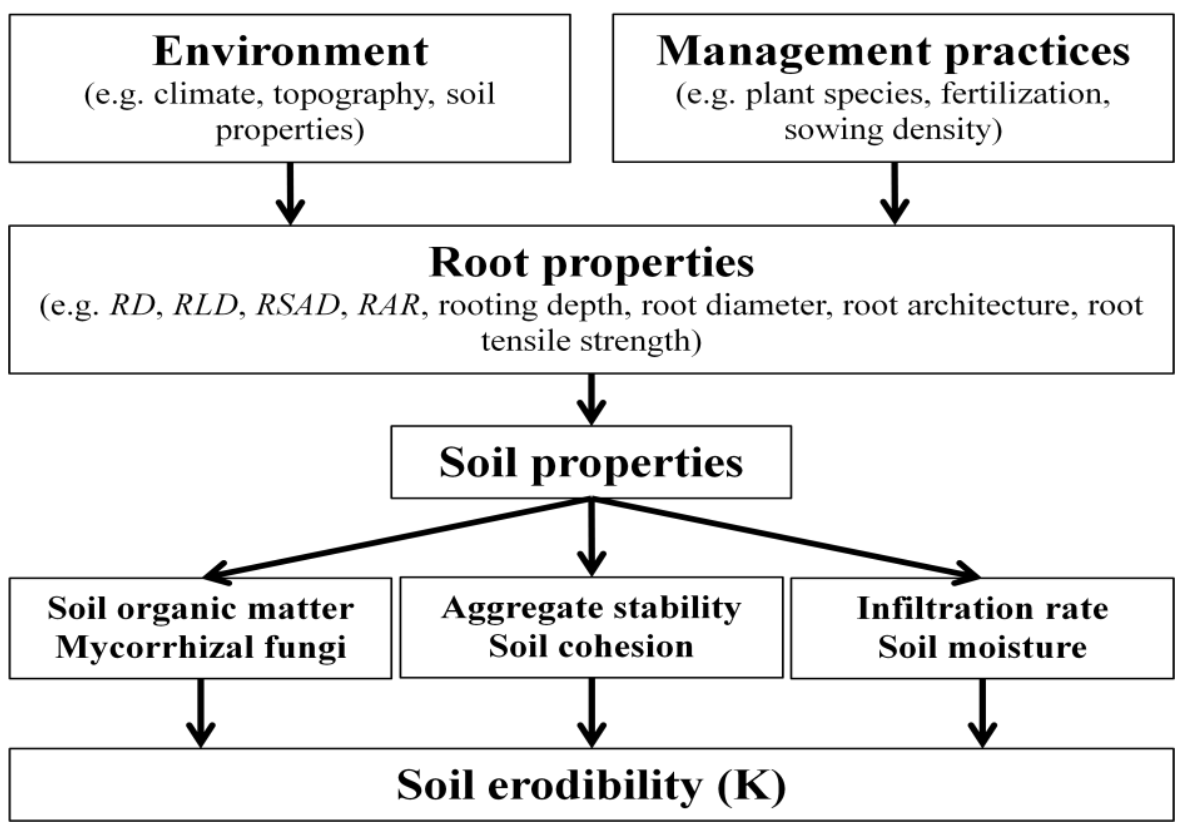

Fig. 2. Overview of factors involved in the erosion-reducing effects of plant roots on soil erodibility. $R D$ $\left(\mathrm{kg} \mathrm{m}^{-3}\right)$ is root density, $R L D\left(\mathrm{~km} \mathrm{~m}^{-3}\right)$ is root length density, $R S A D\left(\mathrm{~m}^{2} \mathrm{~m}^{-3}\right)$ is root surface area density and $R A R(\%)$ is root area ratio. 

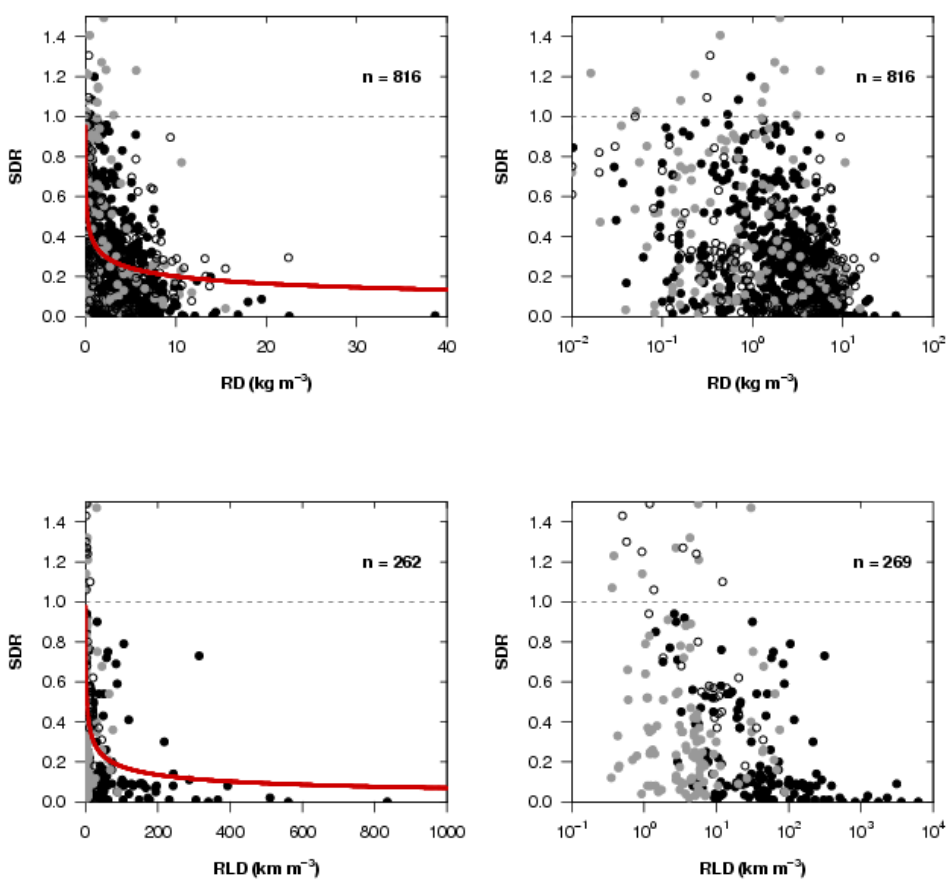

Fig. 3. Soil detachment ratio $(S D R)$ as a function of root density $\left(R D, \mathrm{~kg} \mathrm{~m}^{-3}\right)$ and root length density $\left(R L D, \mathrm{~km} \mathrm{~m}^{-3}\right)$ with an indication of root architecture (•: fibrous roots; $\bullet$ : tap roots and $\circ$ : not available). The dashed line indicates no erosion reduction $(S D R=1)$. Note that the scale of the $\mathrm{X}$-axis in the right figures is logarithmic to better visualize the variability.
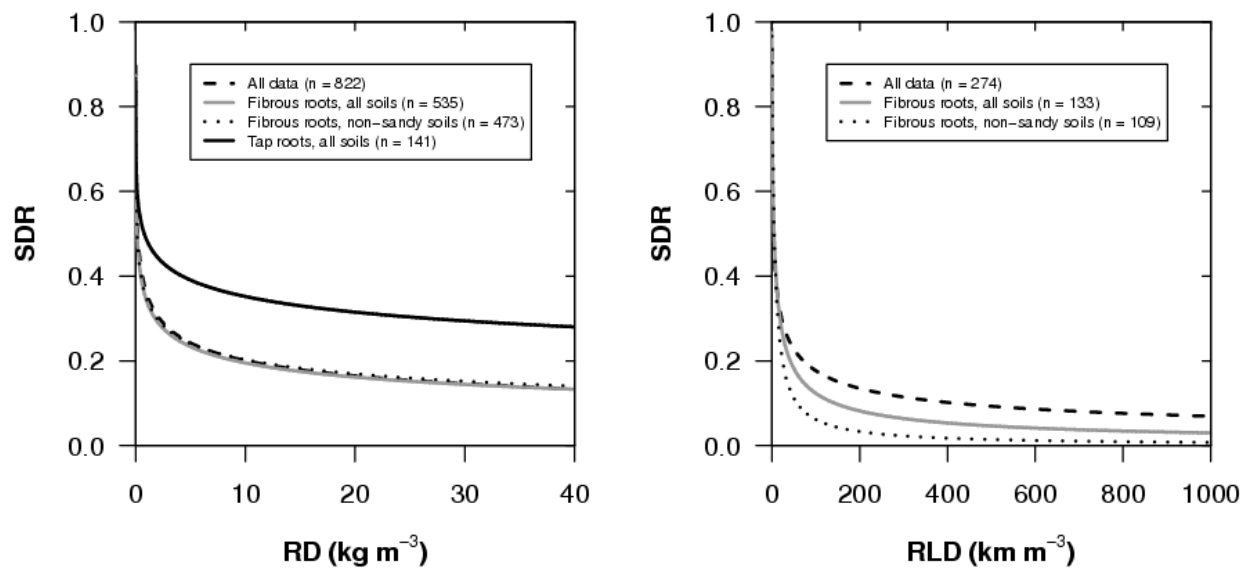

Fig. 4. Plot of significant Hill curve models describing the relation between root density $(R D)$ or root length density $(R L D)$ and soil detachment ratio $(S D R)$ and for the global dataset (all data) and subsets of the global dataset grouped according to root architecture (fibrous, tap roots) and soil texture (non-sandy soils $(<50 \%$ sand $))$. 
Final paper available at: http://www.sciencedirect.com/science/article/pii/S0012825215300350
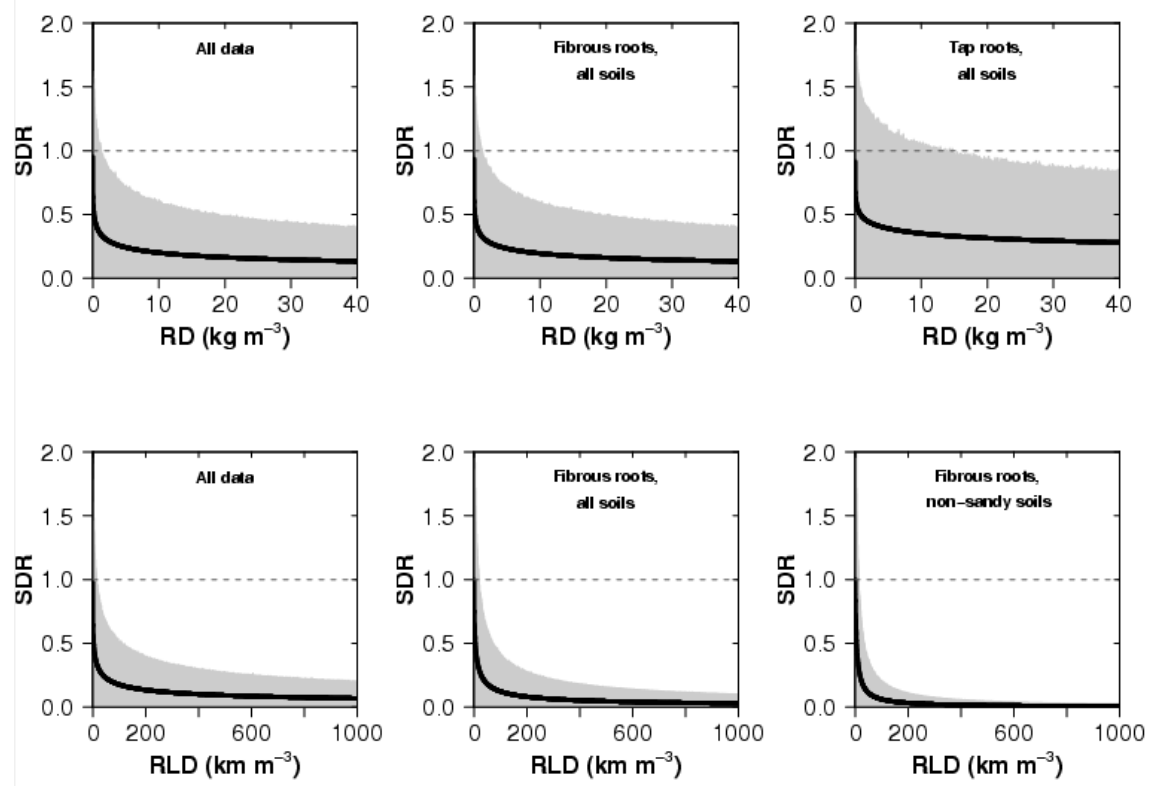

Fig. 5. Uncertainty ranges of the Hill curve models describing the relation between root density $(R D)$ or root length density $(R L D)$ and soil detachment ratio $(S D R)$ for the global dataset (all data) and subsets according to root architecture (fibrous, tap roots) and soil texture (non-sandy soils (<50\% sand)). Grey area indicates the $95 \%$ confidence level of predicted SDR values, dashed lines indicate no erosion reduction $(\mathrm{SDR}=1)$. 
Final paper available at: http://www.sciencedirect.com/science/article/pii/S0012825215300350

\section{Tables:}

Table 1 Overview of empirical studies reporting the effects of a root variable on soil erosion by water. $\triangle \mathrm{AS}$ is soil anti-scourability, CD is rill and gully channel density, CS is rill and gully cross sectional area, $D$ is root diameter, FR is percentage of fine roots, $\mathrm{K}_{\mathrm{i}}$ is interrill erodibility, $\mathrm{K}_{\mathrm{r}}$ is rill erodibility, $R A R$ is root area ratio, $R D$ is root density, $R L D$ is root length density, $R S A D$ is root surface area density, $S D R$ is soil detachment ratio, $R V$ is root volume, $\mathrm{SC}$ is sediment concentration, $S V$ is scour volume, $S Y$ is sediment yield, $\tau_{N}$ is non-uniform stream power. Lab refers to laboratory experiments using either rainfall simulations (1) or hydraulic flume tests (2). Field refers to experiments using rainfall simulations (1), concentrated flow experiments (2), micro erosion plots (3), submerged jet devices (4) and measurements based on rill and (ephemeral) gully cross sections (5) or rill and gully densities (6). NA: not available.

\begin{tabular}{|c|c|c|c|c|c|c|}
\hline $\mathrm{N}^{\circ}$ & Source & Erosion process & Root characteristic (unit) & Root effect/ Original equation & Method & Country \\
\hline \multirow[t]{2}{*}{1} & Ghidey and Alberts (1997) & Splash & Dead RD $\left(\mathrm{kg} \mathrm{m}^{-2}\right)$ & No root effect & Lab_1 & USA \\
\hline & & & $\operatorname{Dead} \operatorname{RLD}\left(\mathrm{km} \mathrm{m}^{-2}\right)$ & & & \\
\hline 2 & Katuwal et al. (2013) & Splash & $\mathrm{RD}\left(\mathrm{kg} \mathrm{m}^{-3}\right)$ & $\mathrm{D}_{\mathrm{r}}\left(\mathrm{g} \mathrm{m}^{-2} \mathrm{~mm}^{-1}\right)=10.48 \mathrm{e}^{-0.80 * \mathrm{RD}}$ & Lab_1 & Belgium \\
\hline 3 & Bui and Box (1993) & Interril & $\operatorname{RLD}\left(\mathrm{cm} \mathrm{cm}^{-3}\right)$ & No root effect & Field_1 & USA \\
\hline \multirow[t]{2}{*}{4} & Ghidey and Alberts (1997) & Interril & Dead RD $\left(\mathrm{kg} \mathrm{m}^{-2}\right)$ & $\mathrm{K}_{\mathrm{i}}\left(\mathrm{kg} \mathrm{s} \mathrm{m}^{-4}\right)=3.55 \mathrm{e}^{-0.71 * \mathrm{RD}}$ & Lab_1 & USA \\
\hline & & & Dead RLD $\left(\mathrm{km} \mathrm{m}^{-2}\right)$ & $\mathrm{K}_{\mathrm{i}}\left(\mathrm{kg} \mathrm{s} \mathrm{m}^{-4}\right)=3.62 \mathrm{e}^{-0.029 * \mathrm{RLD}}$ & & \\
\hline 5 & Pierret et al. (2007b) & Interril and rill & $\operatorname{RLD}\left(\mathrm{cm} \mathrm{cm}^{-3}\right)$ & No root effect & Field_3 & Laos \\
\hline 6 & Zhou and Shangguan (2007) & Interril and rill & $\operatorname{RSAD}\left(\mathrm{cm}^{2} \mathrm{~cm}^{-3}\right)$ & $\mathrm{D}_{\mathrm{r}}\left(\mathrm{kg} \mathrm{m}^{-2} \mathrm{~h}^{-2}\right)=-8.6675 * \mathrm{RSAD}+14.691$ & Lab_1 & China \\
\hline 7 & Zhou and Shangguan (2008) & Interril and rill & $\operatorname{RSAD}\left(\mathrm{cm}^{2} \mathrm{~cm}^{-3}\right)$ & $\mathrm{SY}(\mathrm{kg})=-4936.3 * \mathrm{RSAD}+9163.9$ & Lab_1 & China \\
\hline 8 & Zhang et al. (2012) & Interril and rill & NA & Reduction of $\mathrm{D}_{\mathrm{r}}\left(\mathrm{g} \mathrm{m}^{-2} \mathrm{~min}^{-1}\right)$ & Lab_1 & China \\
\hline \multirow[t]{2}{*}{9} & Katuwal et al. (2013) & Interril and rill & $\mathrm{RD}\left(\mathrm{kg} \mathrm{m}^{-3}\right)$ & $\mathrm{D}_{\mathrm{r}}\left(\mathrm{g} \mathrm{m}^{-2} \mathrm{~mm}^{-1}\right)=35.47 \mathrm{e}^{-0.44 * \mathrm{RD}}$ & Lab_1 & Belgium \\
\hline & & & & $\mathrm{K}_{\mathrm{i}}\left(\mathrm{kg} \mathrm{m}^{-2} \mathrm{~cm}^{-2} \mathrm{~h}\right)=0.50 \mathrm{e}^{-0.41 * \mathrm{RD}}$ & & \\
\hline 10 & Li et al. (1991) & Rill & \#roots $100^{-1} \mathrm{~cm}^{-2}$ & $\operatorname{SDR}(-)=\mathrm{b}_{1} * \mathrm{RD}^{-\mathrm{b} 2} /\left(\mathrm{b}_{3}+\mathrm{RD}^{-\mathrm{b} 2}\right)$ & Field_1 & China \\
\hline \multirow[t]{2}{*}{11} & Mamo and Bubenzer (2001a) & Rill & $\operatorname{RLD}\left(\mathrm{cm} \mathrm{cm}^{-3}\right)$ & $\mathrm{D}_{\mathrm{r}}\left(\mathrm{g} \mathrm{m}^{-2} \mathrm{~s}^{-1}\right)=2.62 \mathrm{e}^{-0.0372 * \mathrm{RLD}}$ & Lab_2 & USA \\
\hline & & & & $\mathrm{D}_{\mathrm{r}}\left(\mathrm{g} \mathrm{m}^{-2} \mathrm{~s}^{-1}\right)=10.33 \mathrm{e}^{-0.166^{*} \mathrm{RLD}}$ & & \\
\hline \multirow[t]{2}{*}{12} & Mamo and Bubenzer (2001b) & Rill & $\operatorname{RLD}\left(\mathrm{cm} \mathrm{cm}^{-3}\right)$ & $\mathrm{D}_{\mathrm{r}}\left(\mathrm{g} \mathrm{m}^{-2} \mathrm{~s}^{-1}\right)=1.65 \mathrm{e}^{-0.127 * \mathrm{RLD}}$ & Field_2 & USA \\
\hline & & & & $\mathrm{D}_{\mathrm{r}}\left(\mathrm{g} \mathrm{m}^{-2} \mathrm{~s}^{-1}\right)=4.65 \mathrm{e}^{-2.33 * \mathrm{RLD}}$ & & \\
\hline \multirow[t]{2}{*}{13} & Cogo and Streck (2003) & Rill & Dead RD + & $\mathrm{SC}\left(\mathrm{kg} \mathrm{ha}^{-1}\right)=0.13 \mathrm{e}^{-0.00027^{*} \mathrm{x}}$ & Field_1 & Brazil \\
\hline & & & buried residue $\left(\mathrm{kg} \mathrm{ha}^{-1}\right)$ & & & \\
\hline \multirow[t]{2}{*}{14} & Liu et al. (2003) & Rill & $\operatorname{RLD}\left(\mathrm{cm} \mathrm{cm}^{-3}\right)$ & $\mathrm{SY}\left(\mathrm{mg} \mathrm{cm}^{-2}\right)=762.22 \mathrm{e}^{-0.3764 * \mathrm{RLD}}$ & Lab_2 & China \\
\hline & & & & $\mathrm{SY}\left(\mathrm{mg} \mathrm{cm}^{-2}\right)=4062.8 \mathrm{e}^{-0.3778 * \mathrm{RLD}}$ & & \\
\hline \multirow[t]{2}{*}{15} & Zhou and Shangguan (2005) & Rill & $\mathrm{RD}\left(\mathrm{mg} \mathrm{cm}^{-3}\right)$ & $\Delta \mathrm{AS}\left(\mathrm{L} \mathrm{g}^{-1}\right)=\mathrm{b}_{1} * \mathrm{RSAD}^{\mathrm{b} 2}$ & Lab_2 & China \\
\hline & & & $\operatorname{RSAD}\left(\mathrm{cm}^{2} \mathrm{~cm}^{-3}\right)$ & & & \\
\hline \multirow[t]{4}{*}{16} & De Baets et al. (2006) & Rill & $\mathrm{RD}\left(\mathrm{kg} \mathrm{m}^{-3}\right)$ & $\operatorname{SDR}(-)=R(L) D^{-b} /\left(a+R(L) D^{-b}\right)$ & Lab_2 & Belgium \\
\hline & & & $\operatorname{RLD}\left(\mathrm{km} \mathrm{m}^{-3}\right)$ & $\operatorname{SDR}(-)=\mathrm{e}^{-\mathrm{b} * \mathrm{R}(\mathrm{L}) \mathrm{D}}$ & & \\
\hline & & & RAR $(\%)$ & $\operatorname{SDR}(-)=a^{*} R(L) D^{-b}$ & & \\
\hline & & & & $\operatorname{SDR}(-)=\mathrm{e}^{-\mathrm{b} * \mathrm{RAR}}$ & & \\
\hline \multirow[t]{2}{*}{17} & Gyssels et al. (2006) & Rill & $\mathrm{RD}\left(\mathrm{kg} \mathrm{m}^{-3}\right)$ & $\operatorname{SDR}(-)=\mathrm{e}^{-2.25 * \mathrm{RD}}$ & Lab_2 & Belgium \\
\hline & & & & $\operatorname{SDR}(-)=\mathrm{RD}^{-0.85} /\left(5.32+\mathrm{RD}^{-0.85}\right)$ & & \\
\hline
\end{tabular}


Final paper available at: http://www.sciencedirect.com/science/article/pii/S0012825215300350

\begin{tabular}{|c|c|c|c|c|c|c|}
\hline 18 & De Baets et al. (2007a) & Rill & $\mathrm{RD}\left(\mathrm{kg} \mathrm{m}^{-3}\right)$ & $\operatorname{SDR}(-)=e^{-2.58 * R D}$ & Lab_2 & Belgium \\
\hline & & & & $\operatorname{SDR}(-)=\mathrm{e}^{-1.45 * \mathrm{RD}}{ }_{1<\mathrm{D}<5 \mathrm{~mm}} * \mathrm{e}^{-0.47 * \mathrm{RD}}{ }_{\mathrm{D}>5 \mathrm{~mm}}$ & & \\
\hline 19 & Knapen et al. (2007a) & Rill & $\mathrm{RD}\left(\mathrm{kg} \mathrm{m}^{-3}\right)$ & $\mathrm{K}_{\mathrm{r}}=\mathrm{e}^{-1.9 * \mathrm{RD}}$ & Lab_2 & Belgium \\
\hline 20 & Zhang et al. (2009) & Rill & $\mathrm{RD}\left(\mathrm{kg} \mathrm{m}^{-3}\right)$ & Decrease of $D_{r}\left(\mathrm{~kg} \mathrm{~m}^{-2} \mathrm{~s}^{-1}\right)$ & Lab_2 & China \\
\hline 21 & De Baets and Poesen (2010) & Rill & $\operatorname{RD}\left(\mathrm{kg} \mathrm{m}^{-3}\right)$ & $\operatorname{SDR}(-)=\mathrm{e}^{-0.93^{*} \mathrm{RD}}$ & Lab_2 & Belgium \\
\hline 22 & De Baets et al. (2011) & Rill & $\mathrm{RD}\left(\mathrm{kg} \mathrm{m}^{-3}\right)$ & $\operatorname{SDR}(-)=\mathrm{e}^{-1.93 * \mathrm{RD}}$ & Lab_2 & Belgium \\
\hline & & & $\operatorname{RLD}\left(\mathrm{km} \mathrm{m}^{-3}\right)$ & $\operatorname{SDR}(-)=\mathrm{e}^{-0.19^{*} \mathrm{RLD}}$ & & \\
\hline 23 & $\mathrm{Li}$ and $\mathrm{Li}(2011)$ & Rill & $\mathrm{RD}\left(\mathrm{kg} \mathrm{m}^{-3}\right)$ & $\mathrm{SY}(\mathrm{kg})=1 /\left(\mathrm{b}_{1}+\mathrm{b}_{2} * \ln (\mathrm{RD})\right)$ & Field_2 & China \\
\hline 24 & Wang et al. (2011) & Rill & $\operatorname{RD}\left(\mathrm{kg} \mathrm{m}^{-3}\right)$ & $\mathrm{K}_{\mathrm{c}}\left(\mathrm{s} \mathrm{m}^{-1}\right)=0.016 \mathrm{e}^{-0.5072^{*} \mathrm{RD}}$ & Lab_2 & China \\
\hline 25 & Bochet et al. (2012) & Rill & $\mathrm{RD}\left(\mathrm{kg} \mathrm{m}^{-3}\right)$ & $\operatorname{SDR}(-)=e^{-0.24^{*} \mathrm{RD}}$ & Lab_2 & Spain \\
\hline & & & $\operatorname{RLD}\left(\mathrm{km} \mathrm{m}^{-3}\right)$ & $\operatorname{SDR}(-)=\mathrm{e}^{-0.25^{*} \mathrm{RLD}}$ & & \\
\hline & & & $\operatorname{RAR}(\%)$ & $\operatorname{SDR}(-)=\mathrm{e}^{-2.53 * \mathrm{RAR}}$ & & \\
\hline & & & $\operatorname{RSAD}\left(\mathrm{m}^{2} \mathrm{~m}^{-3}\right)$ & $\operatorname{SDR}(-)=\mathrm{e}^{-0.000113^{*} \mathrm{RSAD}}$ & & \\
\hline 26 & Burylo et al. (2012) & Rill & $\mathrm{D}(\mathrm{mm})$ & NA & Lab_2 & France \\
\hline & & & $\% \mathrm{FR}$ & & & \\
\hline 27 & Moody and Nyman (2012) & Rill & $\operatorname{RLD}\left(\mathrm{cm} \mathrm{cm}^{-3}\right)$ & $\mathrm{D}_{\mathrm{r}}\left(\mathrm{g} \mathrm{cm}^{-2} \mathrm{~s}^{-1}\right)=\mathrm{b}_{1} * \tau_{\mathrm{N}}{ }^{\mathrm{b} 2} * \mathrm{RLD}^{\mathrm{b} 3}$ & Lab_2 & US \\
\hline & & & & $\tau_{N}\left(0.001 \mathrm{~W} / \mathrm{m}^{2}\right)$ & & \\
\hline 28 & Shit and Maiti (2012) & Rill & $\mathrm{RD}\left(\mathrm{kg} \mathrm{m}^{-3}\right)$ & $\operatorname{SDR}(-)=0.79038 \mathrm{e}^{-1.3537 * \mathrm{RD}}+0.06458$ & Lab_2 & India \\
\hline 29 & Wang et al. (2013) & Rill & $\mathrm{RD}\left(\mathrm{kg} \mathrm{m}^{-3}\right)$ & $\mathrm{D}_{\mathrm{r}}\left(\mathrm{kg} \mathrm{m}^{-2} \mathrm{~s}^{-1}\right)=5.809 \mathrm{e}^{-5.851^{*} \mathrm{RD}}$ & Lab_2 & China \\
\hline 30 & Zhang et al. (2013) & Rill & $\operatorname{RD}\left(\mathrm{kg} \mathrm{m}^{-3}\right)$ & $\operatorname{SDR}(-)=\mathrm{e}^{-0.409 * \mathrm{RD}}$ & Lab_2 & China \\
\hline & & & & $\mathrm{K}_{\mathrm{r}}\left(\mathrm{s} \mathrm{m}^{-1}\right)=0.018 \mathrm{e}^{-0.410^{*} \mathrm{RD}}$ & & \\
\hline 31 & Wang et al. (2014) & Rill & $\mathrm{RD}\left(\mathrm{kg} \mathrm{m}^{-3}\right)$ & $\mathrm{D}_{\mathrm{r}}\left(\mathrm{kg} \mathrm{m}^{-2} \mathrm{~s}^{-1}\right)=0.073 \mathrm{e}^{-0.119 * \mathrm{RD}}$ & Lab_2 & China \\
\hline 32 & Yu et al. (2014) & Rill & $\mathrm{RD}\left(\mathrm{kg} \mathrm{m}^{-3}\right)$ & $D_{r}\left(k m^{-2} s^{-1}\right)=b_{1} e^{-b_{2} * R D}$ & Lab_2 & China \\
\hline 33 & Gyssels et al. (2002) & Rill and gully & $\mathrm{RD}\left(\mu \mathrm{g} \mathrm{cm}^{-3}\right)$ & Decrease of $\mathrm{CS}\left(\mathrm{cm}^{2}\right)$ & Field_5 & Belgium \\
\hline 34 & Gyssels and Poesen (2003) & Rill and gully & $\mathrm{RD}\left(\mathrm{kg} \mathrm{m}^{-3}\right)$ & Decrease of CS $\left(\mathrm{cm}^{2}\right)$ & Field_5 & Belgium \\
\hline 35 & Li et al. (2015) & Rill and gully & $\mathrm{RD}<1 \mathrm{~mm}\left(\mathrm{mg} \mathrm{dm}^{-3}\right)$ & $\mathrm{CD}\left(\mathrm{m} \mathrm{m}^{-2}\right)=-0.1326 * \operatorname{Ln}(\mathrm{RD})+0.8017$ & Field_6 & China \\
\hline & & & $\mathrm{RD} 1-2 \mathrm{~mm}\left(\mathrm{mg} \mathrm{dm}^{-3}\right)$ & $\mathrm{CD}\left(\mathrm{m} \mathrm{m}^{-2}\right)=-0.1103 * \operatorname{Ln}(\mathrm{RD})+0.5233$ & & \\
\hline 36 & Pollen-Bankhead and Simon (2010) & River-bank erosion & $\mathrm{RD}\left(\mathrm{g} \mathrm{cm}^{-3}\right)$ & $\mathrm{RD}=0.5373 * \mathrm{SV}^{-0.9045}\left(\mathrm{~cm}^{3}\right)$ & Field_4 & US \\
\hline & & & & $\mathrm{RD}=0.5756 * \mathrm{SV}^{-1.1859}\left(\mathrm{~cm}^{3}\right)$ & & \\
\hline & & & $\operatorname{RLD}\left(\mathrm{cm} \mathrm{cm}^{-3}\right)$ & $\mathrm{RLD}=61.02 * \mathrm{SV}^{-0.66}\left(\mathrm{~cm}^{3}\right)$ & & \\
\hline & & & $\mathrm{RV}\left(\mathrm{cm}^{3} \mathrm{~cm}^{-3}\right)$ & $\mathrm{RV}=0.44 * \mathrm{SV}^{-0.77}\left(\mathrm{~cm}^{3}\right)$ & & \\
\hline
\end{tabular}


Table 2 Root and soil characteristics of the empirical studies included in the global dataset on the effects of root density $\left(R D, \mathrm{~kg} \mathrm{~m}^{-3}\right)$ and root length density $\left(R L D, \mathrm{~km} \mathrm{~m}^{-3}\right)$ on concentrated flow erosion rates. $N^{\circ}$ refers to the studies listed in Table 1. NA is not available.

\begin{tabular}{|c|c|c|c|c|c|c|c|c|c|c|c|}
\hline \multirow[t]{2}{*}{$N^{\circ}$} & \multirow[t]{2}{*}{ Source } & \multirow[t]{2}{*}{ Plant species } & \multirow{2}{*}{$\begin{array}{l}\text { Root } \\
\text { type }\end{array}$} & \multirow{2}{*}{$\begin{array}{c}R D \text { range } \\
\left(\mathrm{kg} \mathrm{m}^{-3}\right)\end{array}$} & \multirow{2}{*}{$\begin{array}{c}R L D \text { range } \\
\left(\mathrm{km} \mathrm{m}^{-3}\right)\end{array}$} & \multirow{2}{*}{$\begin{array}{c}\text { Sampling } \\
\text { area } \\
\left(\mathrm{cm}^{2}\right)\end{array}$} & \multicolumn{4}{|c|}{ Soil type } & \multirow{2}{*}{$\begin{array}{c}\text { Mean flow } \\
\text { shear } \\
\text { stress } \\
(\tau, \mathrm{Pa})\end{array}$} \\
\hline & & & & & & & USDA & $\begin{array}{c}\% \\
\text { sand }\end{array}$ & $\begin{array}{l}\% \\
\text { silt }\end{array}$ & $\begin{array}{c}\% \\
\text { clay }\end{array}$ & \\
\hline 11 & $\begin{array}{l}\text { Mamo and Bubenzer } \\
\text { (2001a) }\end{array}$ & Lolium perenne $\mathrm{L}$. & Fibrous & NA & $1.44-242.10$ & $\sim 78.5$ & Silt loam & 19 & 57 & 24 & $1.12-3.72$ \\
\hline 12 & $\begin{array}{l}\text { Mamo and Bubenzer } \\
\text { (2001b) }\end{array}$ & Glycine $\max \mathrm{L}$. & Tap & NA & $2.97-6.89$ & $\sim 78.5$ & Silt loam & 19 & 57 & 24 & $2-10$ \\
\hline 33 & Gyssels et al. (2002) & Triticale & Fibrous & $0.66-2.95$ & NA & 125 & Silt loam & 6 & 81 & 13 & NA \\
\hline 34 & $\begin{array}{l}\text { Gyssels and Poesen } \\
\text { (2003) }\end{array}$ & Triticum aestivum, Hordeum vulgare & Fibrous & $0.29-2.34$ & NA & 125 & Silt loam & 10 & 79 & 11 & NA \\
\hline \multirow[t]{3}{*}{14} & Liu et al. (2005) & Hordeum vulgare $\mathrm{L}$. & Fibrous & NA & $21.20-119.50$ & 200 & Silt loam & 15 & 70 & 15 & 20 \\
\hline & & Glycine $\max \mathrm{L}$. & Tap & NA & $4.30-88.50$ & 200 & Silt loam & 15 & 70 & 15 & 20 \\
\hline & & Hordeum vulgare L., Glycine $\max \mathrm{L}$. & NA & NA & $0.50-44.37$ & 200 & Silt loam & 15 & 70 & 15 & 20 \\
\hline \multirow[t]{3}{*}{15} & $\begin{array}{l}\text { Zhou and Shangguan } \\
\text { (2005) }\end{array}$ & Botriochlon ischaemum $\mathrm{L}$. & Fibrous & $0.20-2.51$ & NA & 250 & $\begin{array}{l}\text { Silty clay } \\
\text { loam }\end{array}$ & 8 & 63 & 29 & NA \\
\hline & & Pinus tabulaeformis Carr. & NA & $0.12-2.94$ & NA & 250 & $\begin{array}{l}\text { Silty clay } \\
\text { loam }\end{array}$ & 8 & 63 & 29 & NA \\
\hline & & Robinia pseudoacacia $\mathrm{L}$. & NA & $0.18-2.69$ & NA & 250 & $\begin{array}{l}\text { Silty clay } \\
\text { loam }\end{array}$ & 8 & 63 & 29 & NA \\
\hline 16 & De Baets et al. (2006) & $\begin{array}{l}\text { Poaceae (L. perenne, F. rubra, } \\
\text { F. arundinacea, ) }\end{array}$ & Fibrous & NA & $31.59-6228.77$ & 372.5 & Sandy loam & 56 & 36 & 8 & $9-45$ \\
\hline 17 & Gyssels et al. (2006) & Hordeum vulgare, Glycine max & NA & $0.01-1.83$ & NA & 200 & Silt loam & 15 & 70 & 15 & 20 \\
\hline \multirow[t]{3}{*}{18} & De Baets et al. (2007a) & $\begin{array}{l}\text { Poaceae (L. perenne, F. rubra, F. } \\
\text { arundinacea, ) }\end{array}$ & Fibrous & NA & $2.27-365.75$ & 372.5 & Silt loam & 21 & 70 & 9 & $14-60$ \\
\hline & & D. carota & Tap & NA & $0.38-20.15$ & 372.5 & Silt loam & 21 & 70 & 9 & $14-60$ \\
\hline & & D. carota & Tap & NA & $0.35-9.31$ & 372.5 & Sandy loam & 56 & 36 & 8 & $14-60$ \\
\hline \multirow[t]{4}{*}{21} & $\begin{array}{l}\text { De Baets and Poesen } \\
\text { (2010) }\end{array}$ & $\begin{array}{l}\text { Poaceae (L. perenne, F. rubra, } \\
\text { F. arundinacea, A. sativa, S. cereale) }\end{array}$ & Fibrous & $0.20-38.70$ & NA & 372.5 & Sandy loam & 56 & 36 & 8 & $9-60$ \\
\hline & & $\begin{array}{l}\text { D. carota, } R \text {. sativus, } P \text {. tanacetifolia, } \\
\text { Sinapis alba }\end{array}$ & Tap & $0.13-10.61$ & NA & 372.5 & Sandy loam & 56 & 36 & 8 & $9-60$ \\
\hline & & $\begin{array}{l}\text { Poaceae (L. perenne, } F . \text { rubra, } F . \\
\text { arundinacea, A. sativa, S. cereale) }\end{array}$ & Fibrous & $0.04-16.87$ & NA & 372.5 & Silt loam & 22 & 67 & 11 & $9-60$ \\
\hline & & $\begin{array}{l}\text { D. carota, } R \text {. sativus, P. tanacetifolia, } \\
\text { Sinapis alba }\end{array}$ & Tap & $0.004-15.49$ & NA & 372.5 & Silt loam & 22 & 67 & 11 & $9-60$ \\
\hline 23 & $\mathrm{Li}$ and $\mathrm{Li}(2011)$ & $\begin{array}{l}\text { Poacea (Stipa bungeana, Botriochlon } \\
\text { ischaemum) }\end{array}$ & Fibrous & $0.04-0.62$ & NA & $\sim 36$ & Silt loam & NA & NA & NA & NA \\
\hline \multirow[t]{2}{*}{25} & Bochet et al. (2012) & T. vulgaris & NA & $0.98-13.72$ & NA & 372.5 & NA & NA & NA & NA & 14.6 \\
\hline & & G. scorpius & Tap & $0.33-5.62$ & NA & 372.5 & NA & NA & NA & NA & 14.6 \\
\hline 28 & Shit and Maiti (2012) & $\begin{array}{l}\text { Poacea (Andropogon aciculate, } \\
\text { Eragrostis cynosuroides, Panicum } \\
\text { maxima, Saccharum munja) }\end{array}$ & Fibrous & $0.31-7.14$ & NA & 315 & Sandy loam & 56 & 24 & 20 & $3.8-17.5$ \\
\hline 9 & Katuwal et al. (2013) & L. perenne L. Hugo & Fibrous & $0.53-3.25$ & NA & 20 & Silt loam & 30 & 51 & 19 & NA \\
\hline 29 & Wang et al. (2013) & NA & NA & $0.31-7.86$ & NA & $\sim 75$ & Silt loam & 26 & 61 & 13 & $4.54-22.54$ \\
\hline 30 & Zhang et al. (2013) & Panicum virgatum & Fibrous & $0.30-17.98$ & NA & $\sim 75$ & Loam & 37 & 47 & 16 & $0-20$ \\
\hline 31 & Wang et al. (2014) & NA & NA & $5.10-22.46$ & NA & $\sim 75$ & Silt loam & 24 & 65 & 11 & $5.83-18.15$ \\
\hline \multirow[t]{2}{*}{32} & Yu et al. (2014) & Zea mays, Panicum miliaceum & Fibrous & $0.01-1.04$ & NA & $\sim 75$ & Silt loam & 42 & 54 & 4 & $5.71-17.18$ \\
\hline & & Glycine max, Solanum tuberosum & Tap & $0.004-0.21$ & NA & $\sim 75$ & Silt loam & 42 & 54 & 4 & $5.71-17.18$ \\
\hline
\end{tabular}


Table 3 Parameter estimates and model calibration results. Underlined parameters are significant at 5\%. $R D\left(\mathrm{~kg} \mathrm{~m}^{-3}\right)$ is the root density, $R L D\left(\mathrm{~km} \mathrm{~m}^{-3}\right)$ is the root length density, SDR is the soil detachment ratio, $n$ is the number of observations, $M E$ is the model efficiency, RRMSE is the relative root mean square error.

\begin{tabular}{|c|c|c|c|c|c|c|}
\hline $\begin{array}{l}\text { Relationship } \\
\boldsymbol{R D}\end{array}$ & $\begin{array}{l}\text { Parameter } \\
\text { estimate }\end{array}$ & \multicolumn{2}{|c|}{$\begin{array}{c}95 \% \\
\text { confidence } \\
\text { interval }\end{array}$} & $n$ & $M E$ & RRMSE \\
\hline$S D R=e^{-b * R D}$ & $b: \underline{0.79}$ & 0.66 & 0.96 & 822 & -0.30 & 1.17 \\
\hline$S D R=\frac{R D^{-b}}{c+R D^{-b}}$ & $b: \underline{0.35}$ & $\begin{array}{l}1.61 \\
0.28\end{array}$ & $\begin{array}{l}1.98 \\
0.42\end{array}$ & \multirow[t]{2}{*}{822} & \multirow[t]{2}{*}{0.11} & \multirow[t]{2}{*}{0.96} \\
\hline$R L D$ & & & & & & \\
\hline$S D R=e^{-b * R L D}$ & $b: \underline{0.14}$ & 0.10 & 0.18 & 274 & 0.00 & 1.12 \\
\hline$S D R=\frac{R L D^{-b}}{c+R L D^{-b}}$ & $b: \underline{0.46}$ & $\begin{array}{l}0.37 \\
0.32\end{array}$ & $\begin{array}{l}0.80 \\
0.64\end{array}$ & 274 & 0.17 & 1.02 \\
\hline
\end{tabular}

Table 4 Model calibration and validation results for the Hill curve model based on a non-lineair regression approach using a Monte Carlo simulation with 5000 iterations. Calibration and validation datasets for root density $(R D)$ and root length density $(R L D)$ represent respectively $75 \%$ and $25 \%$ of the global dataset. Median values for model efficiency $(M E)$ and relative root mean square error (RRMSE) are reported together with the possible range of observed $M E$ and $R R M S E$ between brackets. SDR is the soil detachment ratio and $n$ is the number of observations.

\begin{tabular}{lllllll}
\hline \multirow{2}{*}{ Relationship } & \multicolumn{2}{c}{ Calibration } & \multicolumn{2}{c}{ Validation } \\
& $n$ & $M E$ & $R R M S E$ & $n$ & $M E$ & RRMSE \\
\hline \multirow{2}{*}{$S D R=\frac{R D^{-b}}{c+R D^{-b}}$} & \multirow{2}{*}{617} & 0.11 & 0.97 & 205 & 0.11 & 0.93 \\
& & $(0.07-0.18)$ & $(0.81-1.05)$ & & $(-0.07-0.26)$ & $(0.71-1.31)$ \\
$S D R=\frac{R L D^{-b}}{c+R L D^{-b}}$ & \multirow{2}{*}{206} & 0.17 & 1.02 & 68 & 0.15 & 1.02 \\
& & $(0.09-0.26)$ & $(0.86-1.16)$ & & $(-0.82-0.42)$ & $(0.70-1.49)$ \\
\hline
\end{tabular}




\section{Table 5}

Parameter estimates and model calibration results for the Hill curve (Eq. 3) for subsets of the global dataset based on root architecture (fibrous and tap root systems) and soil texture (sand, silt and clay content, \%). Underlined parameters are significant at $5 \% . R D\left(\mathrm{~kg} \mathrm{~m}^{-3}\right)$ is the root density, $R L D\left(\mathrm{~km} \mathrm{~m}^{-3}\right)$ is the root length density, $n$ is the number of observations, $M E$ is the model efficiency, RRMSE is the relative root mean square error. * indicates that observations are derived from only 1 case study.

\begin{tabular}{|c|c|c|c|c|c|c|}
\hline Subset global dataset & $\begin{array}{l}\text { Parameter } \\
\text { estimate }\end{array}$ & \multicolumn{2}{|c|}{$\begin{array}{c}95 \% \text { confidence } \\
\text { interval }\end{array}$} & $n$ & $M E$ & RRMSE \\
\hline \multicolumn{7}{|l|}{$R D$} \\
\hline \multirow[t]{2}{*}{ Fibrous root systems } & b: $\underline{0.33}$ & 0.26 & 0.41 & 535 & 0.13 & 0.81 \\
\hline & c: $\underline{1.93}$ & 1.73 & 2.14 & & & \\
\hline \multirow[t]{2}{*}{ Sand content $<50 \%$} & b: $\underline{0.32}$ & 0.23 & 0.41 & 473 & 0.10 & 0.83 \\
\hline & c: $\underline{1.88}$ & 1.67 & 2.13 & & & \\
\hline \multirow[t]{2}{*}{ Sand content $>50 \%$} & b: $\underline{1.27}$ & 0.88 & 1.80 & 41 & 0.67 & 0.61 \\
\hline & c: $\underline{1.77}$ & 1.29 & 2.52 & & & \\
\hline \multirow[t]{2}{*}{ Tap root systems } & b: $\underline{0.24}$ & 0.03 & 0.49 & 141 & 0.07 & 1.32 \\
\hline & $\mathrm{c}: \underline{1.06}$ & 0.73 & 1.54 & & & \\
\hline \multirow[t]{2}{*}{ Sand content $<50 \%$} & b: 0.22 & -0.05 & 0.55 & 96 & 0.30 & 0.70 \\
\hline & c: $\underline{1.17}$ & 0.69 & 2.06 & & & \\
\hline \multirow[t]{2}{*}{ Sand content $>50 \% *$} & b: $\underline{0.45}$ & 0.06 & 1.02 & 30 & 0.03 & 1.21 \\
\hline & c: $\underline{1.12}$ & 0.65 & 1.93 & & & \\
\hline \multicolumn{7}{|l|}{$R L D$} \\
\hline \multirow[t]{2}{*}{ Fibrous root systems } & b: $\underline{0.66}$ & 0.43 & 0.96 & 133 & 0.27 & 1.08 \\
\hline & c: $\underline{0.34}$ & 0.16 & 0.67 & & & \\
\hline \multirow[t]{2}{*}{ Sand content $<50 \%$} & b: $\underline{0.94}$ & 0.65 & 1.34 & 109 & 0.37 & 1.01 \\
\hline & c: $\underline{0.20}$ & 0.08 & 0.42 & & & \\
\hline \multirow[t]{2}{*}{ Sand content $>50 \% *$} & b: $\underline{1.73}$ & 1.12 & 1.75 & 24 & 0.79 & 0.54 \\
\hline & c: 0.0003 & 0.0002 & 0.005 & & & \\
\hline \multirow[t]{2}{*}{ Tap root systems } & b: 0.19 & -0.11 & 0.54 & 111 & 0.01 & 1.09 \\
\hline & c: $\underline{1.10}$ & 0.64 & 1.88 & & & \\
\hline \multirow[t]{2}{*}{ Sand content $<50 \%$} & b: 0.23 & -0.13 & 0.70 & 93 & 0.02 & 1.10 \\
\hline & c: $\underline{0.94}$ & 0.46 & 1.90 & & & \\
\hline \multirow[t]{2}{*}{ Sand content $>50 \% *$} & b: 0.35 & -0.30 & 1.28 & 18 & 0.03 & 3.04 \\
\hline & $\mathrm{c:} \underline{1.58}$ & 0.76 & 3.69 & & & \\
\hline
\end{tabular}


Table 6 Model calibration and validation results for the Hill curve model (Eq. 3) based on a non-linear regression approach using a Monte-Carlo simulation with 5000 iterations. Calibration and validation datasets for root density $(R D)$ and root length density $(R L D)$ represent respectively $75 \%$ and $25 \%$ of the global dataset. Median values for model efficiency $(M E)$ and relative root mean square error $(R R M S E)$ are reported together with the possible range of $M E$ and $R R M S E$ between brackets.

\begin{tabular}{|c|c|c|c|c|c|c|}
\hline \multirow[t]{2}{*}{ Subset global dataset } & \multicolumn{3}{|c|}{ Calibration } & \multicolumn{3}{|c|}{ Validation } \\
\hline & $n$ & $M E$ & RRMSE & $n$ & $M E$ & RRMSE \\
\hline \multicolumn{7}{|l|}{$R D$} \\
\hline Fibrous root systems & 401 & $\begin{array}{l}0.13 \\
(0.08-0.18)\end{array}$ & $\begin{array}{l}0.81 \\
(0.74-0.87)\end{array}$ & 134 & $\begin{array}{l}0.12 \\
(-0.24-0.27)\end{array}$ & $\begin{array}{l}0.81 \\
(0.66-1.06)\end{array}$ \\
\hline Sand content $<50 \%$ & 355 & $\begin{array}{l}0.10 \\
(0.04-0.17)\end{array}$ & $\begin{array}{l}0.83 \\
(0.75-0.90)\end{array}$ & 118 & $\begin{array}{l}0.09 \\
(-0.46-0.22)\end{array}$ & $\begin{array}{l}0.83 \\
(0.66-1.06)\end{array}$ \\
\hline Tap root systems & 106 & $\begin{array}{l}0.03 \\
(0.00-0.16)\end{array}$ & $\begin{array}{l}1.06 \\
(0.74-1.25)\end{array}$ & 35 & $\begin{array}{l}0.00 \\
(-1.58-0.22)\end{array}$ & $\begin{array}{l}0.99 \\
(0.57-1.73)\end{array}$ \\
\hline \multicolumn{7}{|l|}{$R L D$} \\
\hline Fibrous root systems & 100 & $\begin{array}{l}0.27 \\
(0.14-0.41)\end{array}$ & $\begin{array}{l}1.08 \\
(0.85-1.27)\end{array}$ & 33 & $\begin{array}{l}0.22 \\
(-2.41-0.68)\end{array}$ & $\begin{array}{l}1.08 \\
(0.55-2.24)\end{array}$ \\
\hline Sand content $<50 \%$ & 82 & $\begin{array}{l}0.38 \\
(0.23-0.58)\end{array}$ & $\begin{array}{l}1.01 \\
(0.69-1.26)\end{array}$ & 27 & $\begin{array}{l}0.32 \\
(-3.33-0.82)\end{array}$ & $\begin{array}{l}1.00 \\
(0.42-2.06)\end{array}$ \\
\hline
\end{tabular}

